\title{
Zonguldak ve Karabük Kentlerindeki Anıt Heykellerde İşçi Temsili
}

\author{
BÜLENT ORAL*
}

\begin{abstract}
ÖZ
Heykel, sanatçının elindeki malzemeleri belirli bir anlam ifade edebilecek, bir ağırlığa ve kapsama sahip olabilecek üç boyutlu anlatımlar haline dönüştürmesi olarak tarif edilebilir. Heykelin bir olay, olayın geçtiği yer, kişi/kişiler veya yaşadıkları yere atfen yapılan türüne anıt heykel denir. Bu anıtlar genellikle toplumun sahip olduğu kültür/sanat düzeyi ile paralel olarak kimi zaman hem tarihe hem de topluma mal olup varlığını koruyabilmiş, kimi zaman da çeşitli nedenlere bağlı olarak yok olmuşlardır. Her ne kadar bu tür yapitlar temsiliyette güçlü anlamlar taşıyor olsalar da yok olmalarına neden olan önemli bir etken de içerdikleri anlamın toplum tarafından yeterince kavranamaması veya zamanla zayıflaması suretiyle azalmasıdır. Medeniyetler, tarih boyunca çeşitli amaçlar için anıt heykel yaptırmışlardır. Türk Heykel Sanatı'nda da dönemin ruhuna uygun olarak anıt türünde heykeller ortaya çıktığ1 görülmektedir. Bunlara Atatürk ve Kurtuluş Savaşı'nı konu alan anıt heykeller, Mimar Sinan ve Nasrettin Hoca vb. şahsiyetlerin heykelleri örnektir. Batı Karadeniz Bölgesi Zonguldak ve Karabük illeri Sanayi Devrimi sonucu ortaya çıkan işçi kentleridir. Bu kentlerden Zonguldak kömür madeni işçisi, Karabük ise sanayi işçisi kenti olarak tanınır. Bu makalede Zonguldak ilindeki İşçi Anıtı, Madenci Heykeli, Maden Şehitleri Anıtı, Uzun Mehmet Anıtı, Kozlu Madenci Heykeli incelenmiş, Karabük ilinde ise İşçi Anıt Heykeli ve Atatürk Anıtı incelenerek; kentlerin ekonomik ve nüfus yapısının bel kemiğini oluşturan işçilerin kentteki anıt heykel yapıtlarındaki temsiliyetleri sanat, sanatçı, yönetici sınıf ve toplum arasındaki süregelen ilişkilerin anıt heykellerdeki
\end{abstract}

Yrd. Doç. Dr., Karabük Üniversitesi, Sanat Tarihi Bölümü/KARABÜK

E-posta: bulentoral@karabuk.edu.tr 
yansımalarına yönelik değerlendirmeler sanatsal üslup ve yorumlarla irdelenmiştir. İşçinin temsil edildiği bu anıtlarda en yaygın uygulanmış sanat yaklaşımı klasizimdir. Anıtların çoğunluğunda, işlenen konular idealist yaklaşımlar içerisinde realisttir. Ayrıca geç empresyonist etkide kübist ve soyut anlatımlara sahip anitlar da görmek mümkündür.

Anahtar sözcükler: Anıt Heykel, İşçi, Madenci, Zonguldak, Karabük, Modernizm, Klasisizm.

\section{GİRIŞ}

• nsanlığın yerleşik hayata geçişi ile başlayan süreç Kalkolitik Çağ'da kent Lkavramını doğurmuştur. Kentler, içinde barındırdıkları insanların sosyo-kültürel yapısının ve yaşam tarzının adeta sembolü olmuştur. Ayrıca ait oldukları devletlerin kuruluş felsefe ve doktrinlerini de yansıtan özellikler göstermişlerdir. Bu özellikler kimi zaman kentin bütününde, kimi zaman bir sokak dokusunda, kimi zaman ise yalnız bir anıtta ortaya çıkabilmektedir. Bu nedenle kent dokusunu oluşturan ana etkenleri yansıtan sanatsal anlayış çoğu zaman sembollerle gösterilmiştir.

Anıt terimi (Sözen ve Tanyeli 1994: 22) bir olayın veya kişinin anılması amacı ile yapılan yapıt anlamına gelmektedir. Kelime Osmanlıca'da 'âbid' (sonsuz, ebedi) kelime kökünden türemiştir. Romen dillerinde kullanılan ve İngilizce'ye de geçmiş olan 'monument, monumento' sözcüğü, Latince 'monere' (hatırlamak) kökünden gelmekte ve 'anıyı sonsuza dek yaşatmak' anlamında kullanılmıştır (Kuban 1973: 7-9).

Anıt heykel İslam toplumunda neredeyse hiç itibar görmemiştir. Bunun önemli sebeplerinden biri günümüzde İslam dininin yaygın olduğu coğrafyada yaşayan İslam öncesi toplumların heykellere tanrısal anlamlar yüklemesidir. Bu etki Osmanlı Devleti'nde de görülür. Bunda devletin meşruiyetinin bir ayağını dine dayandırması ve halkın önemli bir kesiminin Müslüman olması önemli etkendir. Her ne kadar Osmanlı Devleti'nde belirttiğimiz nedenlerle heykel sanatına mesafeli durulsa da bu durumun istisnaları vardır. Bunun başlıca örneklerinden biri Avrupa'dan getirdiği heykelleri sarayında konumlandırarak sergileyen Osmanlı Devleti'nin önemli Vezir-i Azamlarından İbrahim Paşa (Pargalı)'dır (Gezer 1984: 7-8). Bir başka örnek ise hem resim sanatına hem de heykel sanatına ilgi duyan ve İtalyan bir sanatçıya yaptırdığ 1 balmumu heykelleri saraya gizlice getirterek muhafaza eden $\mathrm{Pa}$ dişah III. Selim'dir (Cezar 1995: 75-76). Ayrıca Sultan Abdülaziz'in C. F. Fuller'e 1871 yılında yaptırdığı atlı heykeli halk tarafindan tepkiyle karşılanacağ1 endişesiyle saray bahçesine konulmuştur (Erten 2012: 46-47; Yasa 2011: 55). Ancak İslam dünyasında ve Osmanlı sanatında hayvan figürlü heykel 
örnekleriyle karşılaşmak mümkündür. Endülüs Emevi yapısı olan El Hamra Sarayı'nın Arslanlı Havuzu, Diyarbakır Ulu Cami portalinde hayvan mücadelesi rölyefleri ve Osmanlı Dönemi’nde çeşitli saray vb. yapılarının bahçe düzenlemelerinde arslan gibi hayvan figürlerinin yer aldığ 1 heykel örnekleri görülmektedir. Öyle ki Dolmabahçe Sarayı'nın bahçesinde yer alan arslan heykeli Avrupa şehirlerinin meydanlarında karşımıza çıkan anıt heykelleri anımsatmaktadır.

Türk Heykel Sanatı'nda heykeltıraşlara ait yapıtların koleksiyon tarzında korunarak muhafaza edildiği ilk yer 'saray' olmuştur.

$\mathrm{Bu}$ ve benzeri kişisel ya da tekil örnek oluşturacak sanat yaklaşımlarının ortaya çıkardığı sonuç dı̧̧ında Osmanlı sanatında anıt kavramı kapsamında değerlendirilebilecek eserler, saat kuleleri ve figürsüz mimari anıtlardan oluşmuş̧tur (Renda 2002: 139-144). Kuruluşundan itibaren istisnalar dışında heykel sanatına mesafeli duran Osmanlı Devleti'nin, Batılılaşma döneminde bu konudaki tavrında köklü değişimler görülmüştür.

Bu değişim 1882 yılında açılan Mekteb-i Sanayi-i Nefise-i Şahane adlı eğitim kurumunda heykelin eğitim öğretim faaliyetlerine dahil edilmesiyle başlamıştır (Gezer 1984: 8). Yervant Oskan (Erten 2012: 62-63), İhsan Özsoy (Erten 2012: 66-67), Behzat, Mahir Tomruk, Ali Nijad Sirel bu süreçte yetişen heykel sanatçılarıdır. (Aydın 2016: 91-116; Gezer 1984: 15). Ali Nijad Sirel dışında tüm heykeltıraşlar Sanayii Nefise ve sonrasında akademi mezunu olmuşlardır (Tansuğ 2003: 320).

Ancak, Sanayi-i Nefise'de heykel, resme oranla daha ağır işlemekteydi. Bunun temel nedenlerinden biri toplumsal yaşam ile heykel sanatına ilişkin üretim arasındaki dönüşümsel bağlamın oturması için belli bir zaman dilimine ihtiyaç duyulmasıdır. (Özsezgin 2006: 21).

Ülkemizde heykel sanatı alanındaki ilerlemeler 20. yy'ın ilk çeyreğinden itibaren somut olarak görülmeye başlanmıştır. İlk kez Müstakil Ressam ve Heykeltıraşlar Birliği (Giray 1997) üyelerince gerçekleştirilen heykellerde Klasik Yunan heykeli örneklerinin etkileri ile modern Avrupa heykeline değin ortaya konulan birçok eserin etkisi görülür. Sanatsal açıdan belirli bir bütünlük göstermeyen bu eserlerin ortaya çıkışı sanatçılarımızın kimlik arayışlarını da yansıtmaktadır. Osmanlı Devleti’nin hâkim olduğu coğrafya geçmişte heykel sanatının en iyi örneklerinin ortaya çıktığı yer olmasına rağmen, İslam anlayı̧̧ının heykele mesafeli duran yorumlarının etkisiyle olsa gerek bu alanda yetenekli kişiler farklı sanat türlerine yönelmek zorunda kalmıştır. Osmanlı Devleti’nde Batılılaşma dönemi olarak tanımladığımız Tanzimat 
sonrası dönemdeki gelişmeler heykel sanatına karşı önyargının yavaş yavaş ortadan kalkmaya başladığını göstermekte olsa da Avrupa'dan kültürel unsurlar taşınması, bu durumu hızlandırmak için uygulanan bir arayıştan öteye gidememiştir.

Cumhuriyet'in ilanıyla birlikte hızlanan kültürel, sosyal ve siyasal dönüşümlerde özellikle Batı Avrupa'nın etkisi oldukça büyüktür. Değişimler Cumhuriyet'in ilanından önce başlamış olsa bile nihayetinde Cumhuriyet' in ilanıyla yeni bir kimliğe bürünmüş ve böylece bu kimliğe uygun bakış açıları geliştirilmiştir. Mustafa Kemal Atatürk'ün emriyle Heykeltıraş Hikmet Koyunoğlu tarafindan 1924 yılında yapımına başlanarak 1927 yılında tamamlanan Kütahya Şehit Sancaktar Mehmetçik Anıtı bu dönemdeki bakış açısını yansıtan dikkat çekici bir örnektir (Kanberoğlu 2012: 176; Kütahya Tanıtım Büroşürü;). Bu dönemde yerli heykel sanatçısının sanat tavrı görülmeye başlanmış olsa da heykelin resim alanındaki gelişmelerin gerisinde kaldığ $1 \mathrm{da}$ açıktır.

Başlangıçta ülkemizdeki yetişmiş sanatçı azlığı, anıt heykellerin yabancı sanatçılara yaptırılmasını zorunlu kılmıştır. Bu dönemde Heınrıch Krıppel, $\mathrm{P}_{1-}$ etro Canonica, Anton Hanak ve Josef Thorak gibi yabancı sanatçılara anıt heykeller yaptırılmış, (Berk, Gezer 1973: 55; Gezer 1994: 75-83) böylece bat1lı sanatçıların kültürel alandaki gelişmelerde Cumhuriyet'e katkıları önemli olmuştur. Bunun sonucu olarak Heınrıch Krıppel tarafindan kamusal alana ilk heykel (Atatürk Heykeli) dikilmiştir (Erten2012: 106-107).

1937 yılında Rudolf Belling’in Türk heykeltıraş yetiştirmek üzere görevlendirilmesi dikkat çekicidir. Tam da bu süreçte Avrupa'ya yetiştirilmek üzere gönderilen yerli heykel sanatçlarımız ülkemize henüz geri dönmektedirler. Böylece ilerleyen yıllarda yerli heykeltıraşlar daha kapsamlı anıt türünde yapıtlar ortaya koymaya başlamışlardır. Seçilen konular, Cumhuriyet' in ilanıyla başlayan süreçteki politik yaklaşımlara uygun çalı̧̧maları daha da çeşitlendirmiştir. Böylece ülkenin öne çıkan tarihsel figürleri ya da sembolleri kent meydanlarındaki kamusal sanat alanlarına (Kedik 2011: 229-240) taşınmaya başlanmıştır. Sanat eğitimi veren kurumlar heykel sanatı alanında yetenekli görülen öğrencilerden oluşturulmuştur. Bu öğrenciler hem ülkemizde hem de Avrupa'da aldıkları eğitimin etkisiyle heykel sanatı alanında önemli gelişim göstermişlerdir. Bu süreç öğrencilerin yeteneklerini, ülkelerindeki tarihsel dokuya yansıtmasının önünü açmıştır. Öncesinde heykel sanatı alanında çalı̧̧ma yaptırılacak yetkin yerli sanatçı bulunmadığı kanaati oluştuğundan çoğunlukla yurtdışından getirilen sanatçılara anıt heykeller yaptırılmıştır. Bu yönüyle işlenmesi istenen konunun bir anıta taşınması daha uzun ve pahalı 
olmuştur. Sanat kurumlarının varlığı heykel sanatı alanında hem yetenekli hem de heykel sanatı tarihi hakkında bilgi sahibi bir nesil yetiştirmeyi amaçlamıştır. Böylece sanatçıların kendi ülkelerinin tarihi dokusu ile ilgili yapıtlarını mekanlardan kamusal alana taşıması daha hızlı ve kolay olmuştur. Bu yönüyle sanat eğitimi veren kurumlar ile anıt türünde heykel yapılması arasında doğrudan bir bağ kurulamasa da dolaylı bir ilişki olduğunu savunabiliriz.

Anıt heykelde işlenen konular genellikle Cumhuriyet'in ilanı ve Milli Mücadele'de yer almış kişiler olmuştur. Bunların arasında en fazla görülen Atatürk heykelleridir ${ }^{1}$. Atatürk konulu anıt heykellerde çoğu zaman işlenen tema yalnızca Atatürk'tür. Ancak kent meydanlarında yapılan bazı Atatürk konulu anıtlar, kentin coğrafi ekonomik ve siyasal özellikleriyle ilişkili bir tema içinde ele alınmıştır. Bunun dışında Kurtuluş Savaşı konularının işlendiği anıt heykeller ve kentlerle özdeşleşmiş kişi veya olaylar, şehirlerin ekonomik kaynakları, çalışanları ile gündelik yaşamlarında öne çıkan simgeler de anıt heykellerin temasını oluşturmuştur.

Cumhuriyet'le birlikte yeni bir durum ortaya çıkmıştır. Atatürk heykellerinin (Tekiner 2010) ülkenin dört bir yanından sipariş edilmesi ile ilk kez anıt heykeller belirgin olarak kamusal alana taşınmıştır.

Cumhuriyet'in ilanı aynı zamanda Modern Avrupa'nın yaşam ve kültür özelliklerini içselleştiren bir dönem ortaya çıkarmıştır. Bu dönem Sanayi-i Nefise'nin kuruluşundan sonra başlayan sanat alanındaki gelişmelere hız verilen bir evredir. Sanat eğitimi süreç içerisinde yasal düzenlemelerle yenilenmiş, ülkemize Avrupa'dan sanatçılar eğitim vermek üzere getirtilmiş, yetenekli görülen öğrenciler ise yurtdı̧ına eğitime gönderilmiştir. Bu dönemdeki sanatçılar devlet tarafindan desteklenmiş, Halkevleri aracılığıyla sanat, sanatç1 ve toplum buluşması sağlanmıştır (Kıvanç 2003: 8). Cumhuriyet, toplumda istendik kültürel ve ideolojik değişimler yaratmak suretiyle halkın modern sanat alanındaki gelişmeleri özümsemesini sağlamak için heykel sanatından yararlanmış ve bu amaç doğrultusunda modern sanat alanındaki gelişmeleri özenle takip etmiştir.

1940-1960 yılları arasında Türk heykeltıraşlarının kaydettiği ilerleme ve açık görüşlülük sayesinde heykel sanatı büyük bir atılım yapmıştır. Özellikle yurtdışında başarı elde eden sanatçılarımız yurda döndüklerinde daha emin adımlarla ilerlemiş ve Modern Türk Sanatı’nın öncüleri olmuşlardır (Coşkun 2011: 135). Bu dönem sanatçıları arasında Ali Hadi Bara (Yılmaz 2006) ve

1 Atatürk heykellerinin hızlıca ülkenin dört bir yanına gerçekleştirme gayretleri beraberinde anıt heykelde estetik tartı̧̧ması da doğurmuştur (Sabahat 2017: 963). 
Zühtü Müridoğlu'nun öne ç1ktığ1 görülmektedir (Yasa, Yaman 1992: 142). Bu sanatçılara 1955 yılında İlhan Koman ve 1959 yılında Şadi Çalık gibi sanatçılar da dahil olmuştur. Böylece Modern Türk Heykel Sanatı'nda büyük gelişmeler sağlanmıştır (Bulat, Bulat, Yağmur ve Aydın 2014: 366).

Ülkemizde 1980 sonrasında heykel sanatçılarının tutunmaya çalıştığı önemli alanlardan biri de anıt heykeller olmuştur. Bunun başlıca nedenlerinden biri anıt heykellerin ekonomik getirisinin yüksek olmasıdır. Anıt heykelleri yaptıran kuruluşlar kamusal alana konumlandırılacak yapıtın oluşumundaki masraflardan çoğunlukla kaçınmamışlardır. Böylece heykeltıraşlar ekonomik olarak ayakta durabilecekleri bir alan bulabilmişlerdir.

Aynı dönemde sıkça gerçekleştirilen, günümüzde de gerçekleştirilmeye devam edilen, bir diğer etkinlik ise taş sempozyumları'dır.

Heykellerini geleneksel dinamiklere dayalı unsurlar üzerine kuran heykel sanatçıları, üretimlerini anıt heykel ve heykel sempozyumlarında da göstermişlerdir.

1980 ve sonrasında sanatçı tavrında değişimler görülmüştür. Özellikle iletişim çağının ülkemize yansımaları kitle iletişim araçlarının çeşitlenmesi ve dünyadaki gelişmelerin önceki yıllara nazaran daha hızlı yayılması sanatçıların da tavırlarında değişimler ortaya çıkarmıştır. Bu süreç içerisinde sanatç1lar daha bireysel yaklaşımlar gösterebilmişlerdir. Gündeme ilişkin gelişmelere gösterilen tepkilerin bireyselleşmesine paralel olarak sanatçı yaklaşımlarında da bireyselleşme görülür. Sanatçılar, yapıtlarını hem heykel sanatı içindeki gelişmeler hem de kendi belirledikleri kurallar çerçevesinde ortaya koyabilmişlerdir. Çalışmaya konu olan anıt heykellerde her iki durumu da gözlemlemek mümkündür.

1980 sonrası Alpaslan Baloğlu, Canan Beykal, Cengiz Çekil, Osman Dinç, Ayşe Erkmen, Serhat Kiraz, Füsun Onur, Ahmet Öktem, Ergül Özkutan ve İsmail Saray gibi sanatçılar, çalışmalarıyla çă̆daş sanatın Türkiye'de farklı bir yol çizmesini sağlarken hemen hemen aynı kuşağın heykel sanatçıları heykelin geleneksel çizgilerini (kütle-mekân-form) kendi üsluplarında yorumlamışlardır (Yüksel 2012: 98).

\section{ANIT HEYKELLERIN KONUMU VE İŞÇİ TEMSİLI}

Anıt heykel genellikle kamusal alanın en güçlü olduğu yerlere yapılmaktadır. Anıtın gerçekleştirileceği yerin belirlenmesi gerçekleştirme sürecinin sadece bir parçasıdır. Kamusal alan her türden sanatsal, sosyal, politik ve benzeri etkinliklerin gerçekleştirildiği yerdir. Bu alan, kentin büyük oranda buluşma 
noktasıdır ve amaç edinilen mesaj en iyi burada karş1lı bulabilecektir. Ü1kemizdeki anıt heykel çeşitliliğinde önemli bir yere sahip olan işçi temsiline yönelik anıtlar çoğunlukla maden işletmeciliğinin geliştiği kentlerde ortaya çıkmıştır. Sanayi Devrimi'nin etkisiyle ortaya çıkan maden işletmeleri, beraberinde toplumun önemli bir kesiminin dahil olduğu maden ve sanayi işçisinin ülkemizde kavramsallaşması sonucunu doğurmuştur.

1948 y1lı maden işletmeciliği tarihinde maden şirketlerinin en yüksek kazancı sağladığı yıldır. Günümüzde bazı madenlerin değeri tüm madencilik tarihinin en yüksek noktasındadır. Bu nedenle hem maden işletmecilerine hem de işletmelere ilgi her zamankinden daha yüksektir. Bu durum ülkemizdeki madencilik faaliyetlerinin diğer ülkelerde olduğu gibi öne çıkan bir faktör olmasını kaçınılmaz kılmaktadır (Avşaroğlu 2008: 21). Madenciliğin ülke ekonomisinde gittikçe başat rol alması beraberinde maden ocakları ve maden işçileri gerçeğinin toplumda tanınmasını sağlamış, madencilerin çalışırken yaşadıkları koşulların zorluğu geniş halk kitlelerinin dikkatini çekmiş, bu duruma kurumlar ve sanatçılar da kayıtsız kalmamışlardır. Maden işletmelerinin belirli bir bölgede gelişim göstermesi beraberinde maden ve sanayi işçilerinin o bölgede istihdamını sağlamış ve buna dayalı bir kent dokusunu ortaya çıkarmıştır. Böylece işçi kentleri ismiyle tanımlayabileceğimiz (Zonguldak, Karabük vb.) şehirler doğmuştur.

Bu iki kent dışında İstanbul, Ankara, Soma ve Amasra kentlerinde de işçinin temsil edildiği anıt heykeller yaptırılmıştır. İşçi temsili temasıyla öne çıkan anıt heykellerden İstanbul Tophane İşçi Heykeli ve Ankara Madenci Anıtı zaman zaman kamuoyunun gündemine taşınmış bilinen yapıtlardandır. Günümüzde yerinden kaldırılmış olan Tophane İşçi Heykeli hakkında Meltem Ahıska'nın 'Hatırlayan Ucubeler: Tophane'deki İşçi Anıtının Hikayesini Sürmek' başlıklı makalesi bu bağlamda dikkat çekicidir (Ahıska 2011: 1-21). Yazar, İşçi Anıtı'nın geçirdiği süreç üzerinden ülkemizdeki anıt heykel sanatına bakışı tarihsel süreç içerisinde sanat, toplum, siyaset, ideolojik yaklaşımlar bağlamında bilimsel çerçevede ele alarak kişisel eleştirilerle işlemiştir. İşçinin ele alındığı diğer çalışma ise, Bülent Oral'ın 'Bir Anıtın Enstalasyona Dönüşümü: Zonguldak Havzası Maden Şehitleri Anıtı' başlıklı makalesidir. Bu makalede anıt ve enstalasyon kavramları tanımlanarak Zonguldak Havzası Maden Şehitleri Anıtı'nın bir süreç içerisinde uğradığg değişim kuramsal olarak irdelenmiştir (Oral 2017).

Bu makaleye konu olan Zonguldak ve Karabük kentleri Sanayi Devrimi'nin getirdiği teknolojik gelişmelere bağlı olarak ortaya çıkan hammadde ihtiyacını karşılayan işçi kentleri olarak kurulmuşlardır. Zonguldak 1829 yılında 
yalnızca bir köy iken; kömür madeninin bulunması ile şehirleşme sürecine girmiştir. Kent 1841 y1lından itibaren idari ve sosyo-ekonomik açıdan gelişerek 1899 'da kaza 1920'de mutasarrıflık haline gelmiştir. Milli Mücadele'den sonra 1924 yılında il olmuştur. Zonguldak Cumhuriyet'in ilk illerinden biri$\operatorname{dir}$ (Genç 2010: 137-152). Bu gelişme kentin ekonomik gelir kaynaklarından olan kömür madeninden kaynaklanmıştır. Özellikle kömürün Zonguldak ilinde bulunmasıyla beraber bölgeye çoğunlukla Avrupalı mühendisler eliyle maden ocağ 1 işletmeleri açılmış böylece yöre yeni bir çehreye kavuşmuştur.

Başlangıçta Zonguldak’a bağlı bir ilçe olan Karabük 1995 yılında il yapılmıştır. Her iki şehir de günümüze değin işçi kenti olarak adlandırılmaktadır. Bu değerlendirme bir benzetme değil, bilakis adı geçen şehirlerin kimliğidir. Karabük ili, Zonguldak ilinde olduğu gibi işçi kenti olarak kurulmuştur. Karabük, başlangıçta çok küçük bir yerleşim yeri iken, bölgeye 1937 yılında kurulan Demir Çelik Fabrikası'nın 1939 yılında üretime başlamasıyla² birlikte hızla büyük bir yerleşim alanına dönüşmüştür. Cumhuriyet'in ilk yıllarında heykel dökümleri için Karabük Demirçelik Fabrikası'ndan faydalanıldığı da bilinmektedir. Kente kurulan fabrikaya çok yakın bir mesafede tarihi dokusu ile Safranbolu yer almasına rağmen Karabük bundan bağımsız bir şekilde 118 büyümesini sürdürmüş ve vilayet olmuştur.

Zonguldak ve Karabük kentleri günümüzde de maden ve sanayi kenti olma vasıflarını sürdürmektedir. Bu durum 100 yılı aşkın süredir devam etmektedir. Her iki kentte açılan üniversiteler kentlerin ekonomisine olumlu katkılar sağlamış olsa da; kömür, demir-çelik sanayisi Zonguldak ve Karabük kentleri için halen birincil önemini korumaktadır. Bu durum kentlerdeki sanatsal etkinliklerde işçi ve iş̧̧i temsili temalarının öne çıkışını etkilemiştir.

\subsection{Zonguldak’taki İşçileri Temsil Eden Anıt Heykeller}

Zonguldak kentindeki işçi anıt heykelleri birkaç farklı türde ele alınmıştır. Bunlar tek başına işçi heykeli ile temsil, bir kompozisyon içinde temsil ve figüre yer verilmeyen anıt ile temsil olarak karşımıza çıkmaktadırlar. Bu makalede Zonguldak’taki işçi temsilini ortaya koyan beş anıt irdelenmiştir. Bunlar İşçi Anıtı, Zonguldak Havzası Maden Şehitleri Anıtı, Madenci Anıtı, Ereğli Uzun Mehmet Anıtı (Madenci Heykeli) ve Kozlu³ Madenci Heykeli'dir.

TMMOB Sanayi Kongresi 2007 Oda Raporu, s. 103.

3 Bu makalenin yayını aşamasında Kozlu Belediyesinin bulvar çalışması sırasında şehrin girişine ekim ayında ikinci bir Madenci Heykeli yaptırılmıştır (http://www.milliyet.com.tr/baskan-yilmaz-danornek-davranis-zonguldak-yerelfotogaleri-25395887 Erişim tarihi: 16.11.2017). Bu nedenden ötürü heykel ile ilgili incelemeler Zonguldak’taki İş̧i Heykelleri başlığına taşınmamıştır. Anıtta kömür ma- 


\subsection{1 İşçi Anıtı:}

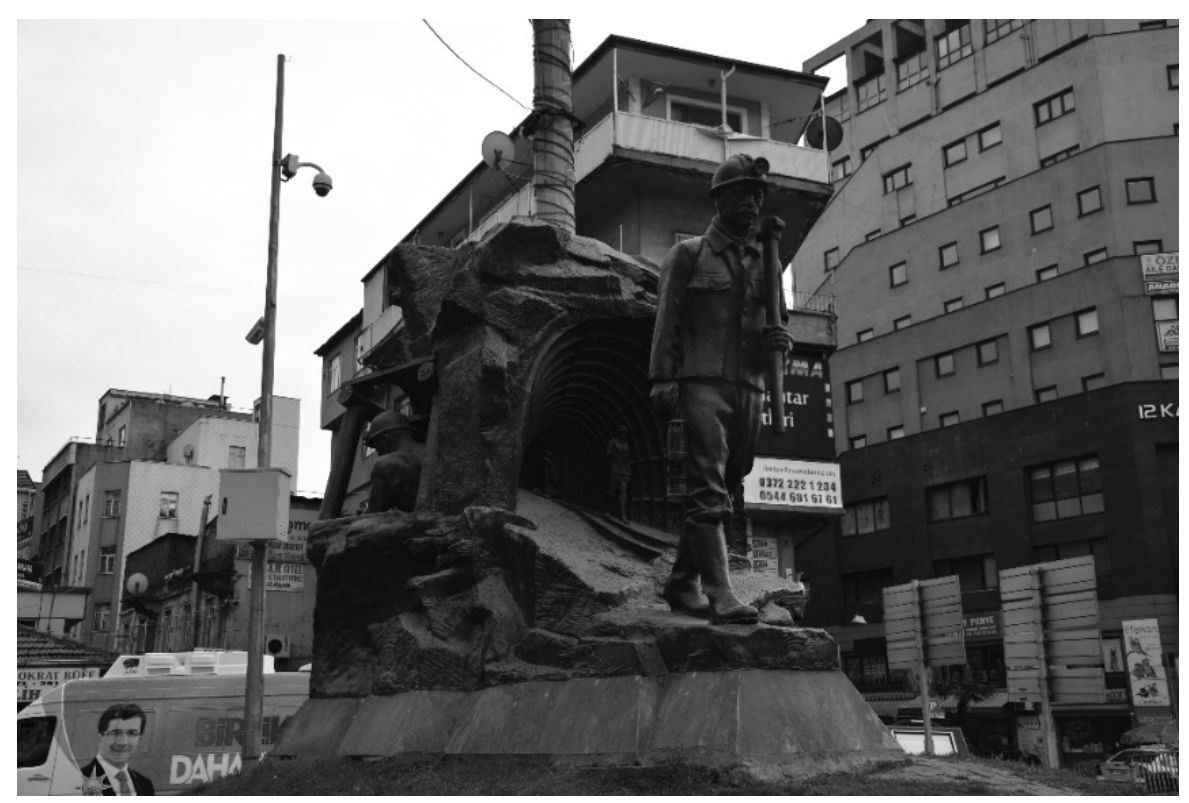

Fotoğraf 1: Tankut Öktem (1986), İşçi Anıtı, Zonguldak

Anıt, Heykeltıraş Tankut Öktem tarafından 05.07.1986 tarihinde yapılmı̧̧ olup $1465 \mathrm{~kg}$ ağılığındadır ve malzemesi bronzdur (Fotoğraf 1 ). Heykeltıraş eserinde anıtın yapıldığı zaman diliminde yaşayan işçileri model olarak kullanmıştır.

Anıtta, bir maden ocağı kompozisyon biçiminde ele alınmıştır. Kompozisyonda bir madencinin çalışma koşulları, madenden eve dönüşü ve ailesiyle buluşmasının yanı sıra, ülkenin çeşitli yerlerinden gelerek maden ocaklarında çalışmaya başlayan diğer madencileri temsil eden figürler betimlenmiş ve kompozisyon Mustafa Kemal Atatürk'ün kent hakkındaki özdeyişi ile tamamlanmıştır (Fotoğraf 2).

deninin zemini belirleyen kömür parçaları üzerine hilal ve hilalin içinde maden işçisini temsil eden elindeki kırma aletleriyle maden ocağından kömür çıkarmakta olan madenci görülmektedir. Anıt heykel Klasik Heykel Sanatı anlayışında ele alınmıştır. İşçinin elindeki aletlerle kömürü çıkarırken biçimsel olarak ülkemizin bayrağını tamamlayan hilale dönüşür. Böylece maden işçisinin ülkenin varlığına katkısı anıta taşınmıştır. 


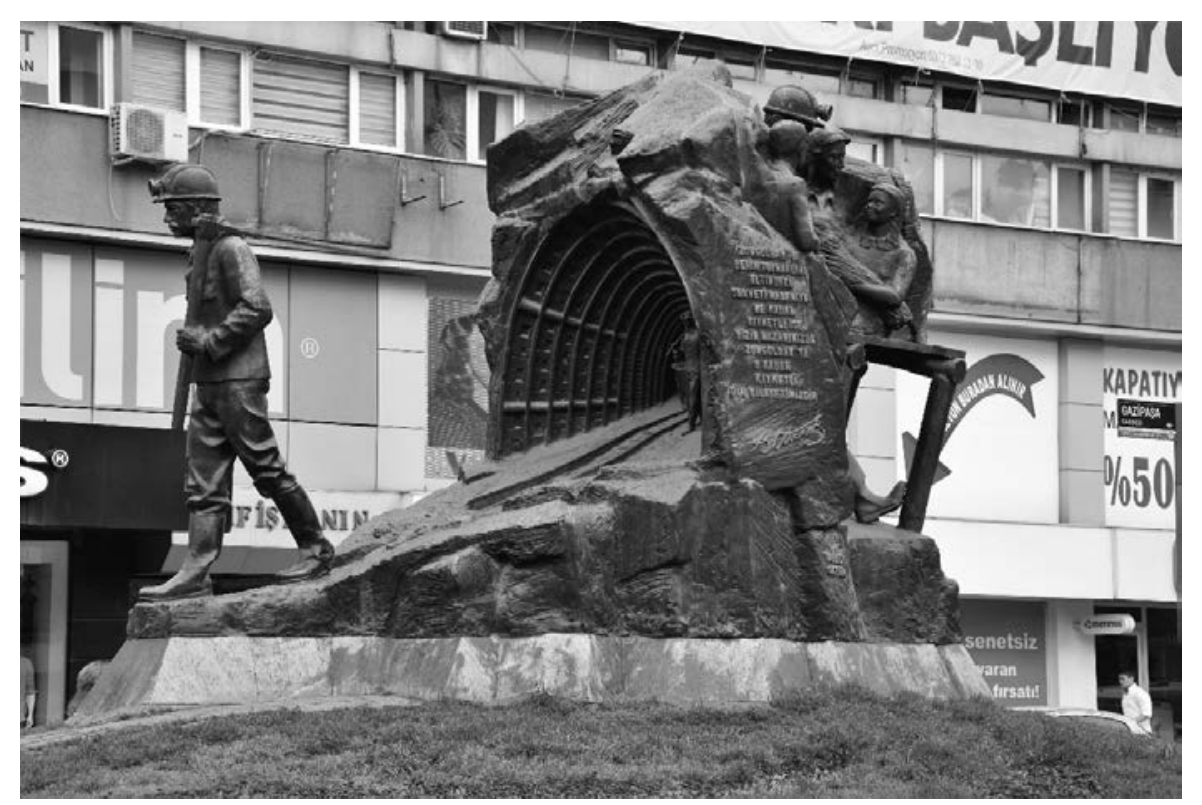

Fotoğraf 2: Tankut Öktem (1986), İşçi Anıtı, Zonguldak

Anıt, kentin ana yollarının kesiştiği kavşaktaki (işçi meydanı) yüksekçe bir platform üzerine yaptırılmıştır. Anıtın ön yüzünde yer alan figür henüz maden ocağından yeni ayrılmakta olan bir madenciyi göstermektedir ${ }^{4}$. Madenci, üzerindeki iş kıyafeti, başındaki bareti, omuzuna yasladığı kazma ve elinde tuttuğu gaz lambası ile yürümektedir. Baretinde fener bulunmasına ve heykelin yapıldığı dönemde daha modern gereçler (el feneri vb.) kullanılıyor olmasına rağmen işçinin eline gaz lambası tutuşturulmuştur. Modern çağın madencilikteki öne çıkan sembolü işçi ve elindeki gaz lambasıdır. Gaz lambası madencinin olmazsa olmaz sembollerinden biridir. Bu sembollerden bir diğeri de kazmadır. Omuzda kazma ile ocaktan çıkılması aynı zamanda iş bittikten sonra bile madencinin taşımak zorunda olduğu iş yükünün sürekliliğini sembolize eder. Böylece bu figürdeki kazma aynı zamanda işçinin adeta omuzuna binmiş ağırlığ 1 da betimler. Bu durum heykeltıraşın simgesel anlatımı göz önünde bulundurmasına neden olmuştur. Sanatçı klasik dönem anlatımcilı̆ını postmodern dönemde ifade etmeye devam eder. Bu işçi figürü anıtın yüksekliğine denk bir boya sahiptir. Anıtın tünel girişinde başka bir işçi daha çıkışa doğru yürümektedir. Bu işçinin arkasında ise bir vagon ve

4 Heykeltıraş Tankut Öktem bu işçi modeli olarak dönemin Genel Maden İşçileri Sendikası Genel Başkanı Mehmet Tezer'i kullanmıştır. 
vagonun çevresindeki işçiler betimlenmiştir. Anıtın ön cephesindeki derinlik algısı güçlüdür ve bu derinlik algısı tünel boyunca sağlanmıştır. Tünelin ağzı geniştir ve ilerledikçe tünel daralmaktadır. Ayrıca figürlerin görüntüleri derinlik arttıkça küçülür, böylece oluşturulan perspektif anıtın ön cephesinde güçlü bir gerçeklik algısı yaratmaktadır (Fotoğraf 3).

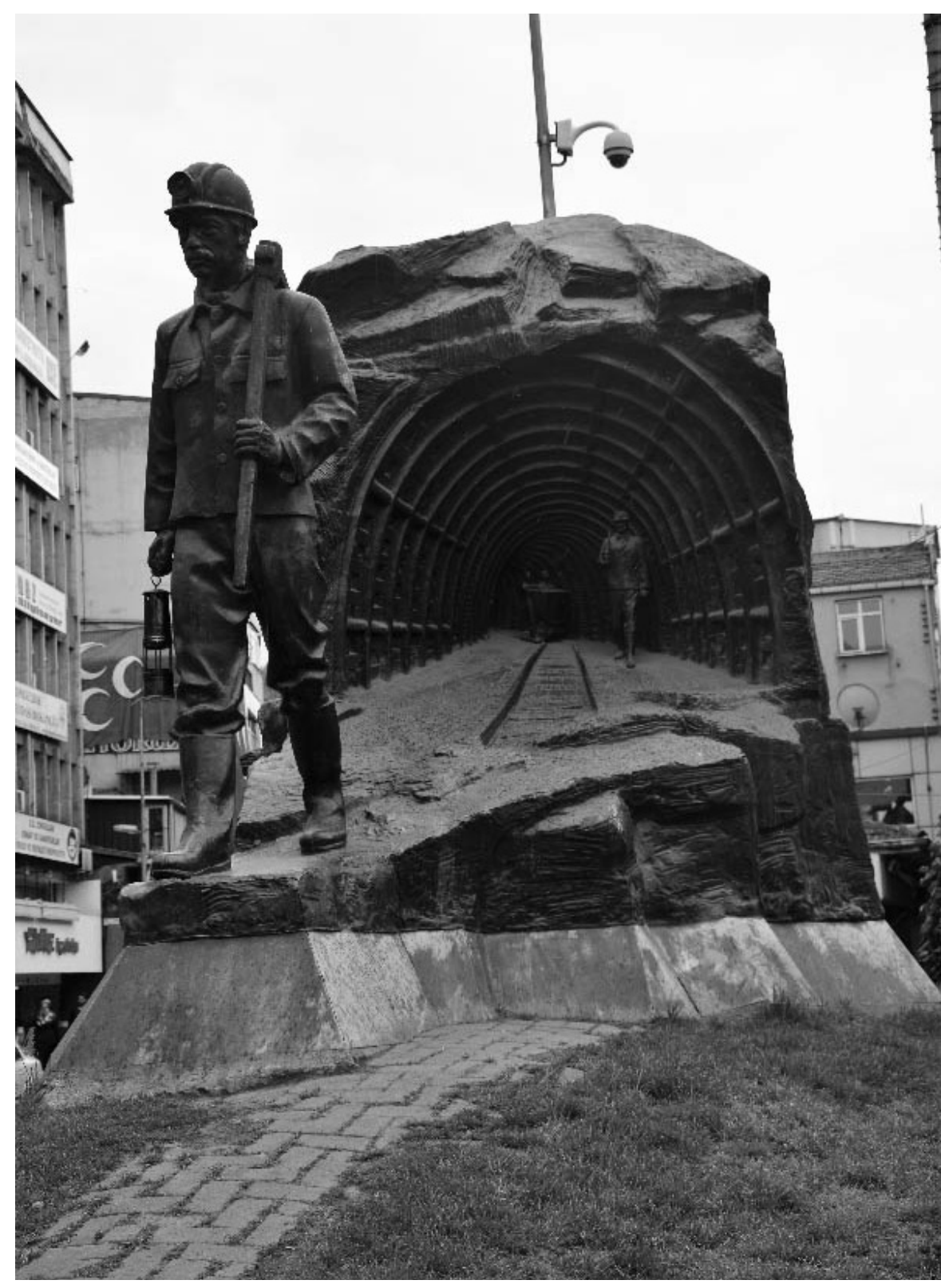

Fotoğraf 3: Tankut Öktem (1986), İşçi Anıtı, Zonguldak 
Anıtın batı cephesinde bir yazıt ve ailesiyle birlikte betimlenmiş işçi görülür. Anıtın bu cephesinde Mustafa Kemal Atatürk'ün 1931 yılında ifade ettiği 'Zonguldak'in derin toprakları altındaki serveti madeniye ne kadar kıymetli ise, bizim nazarımızda Zonguldak'ta o kadar değerli bir vilayetimizdir." cümlesi yer alır. Yazıtın altında Mustafa Kemal Atatürk'ün imzası yer alır (Fotoğraf 4).

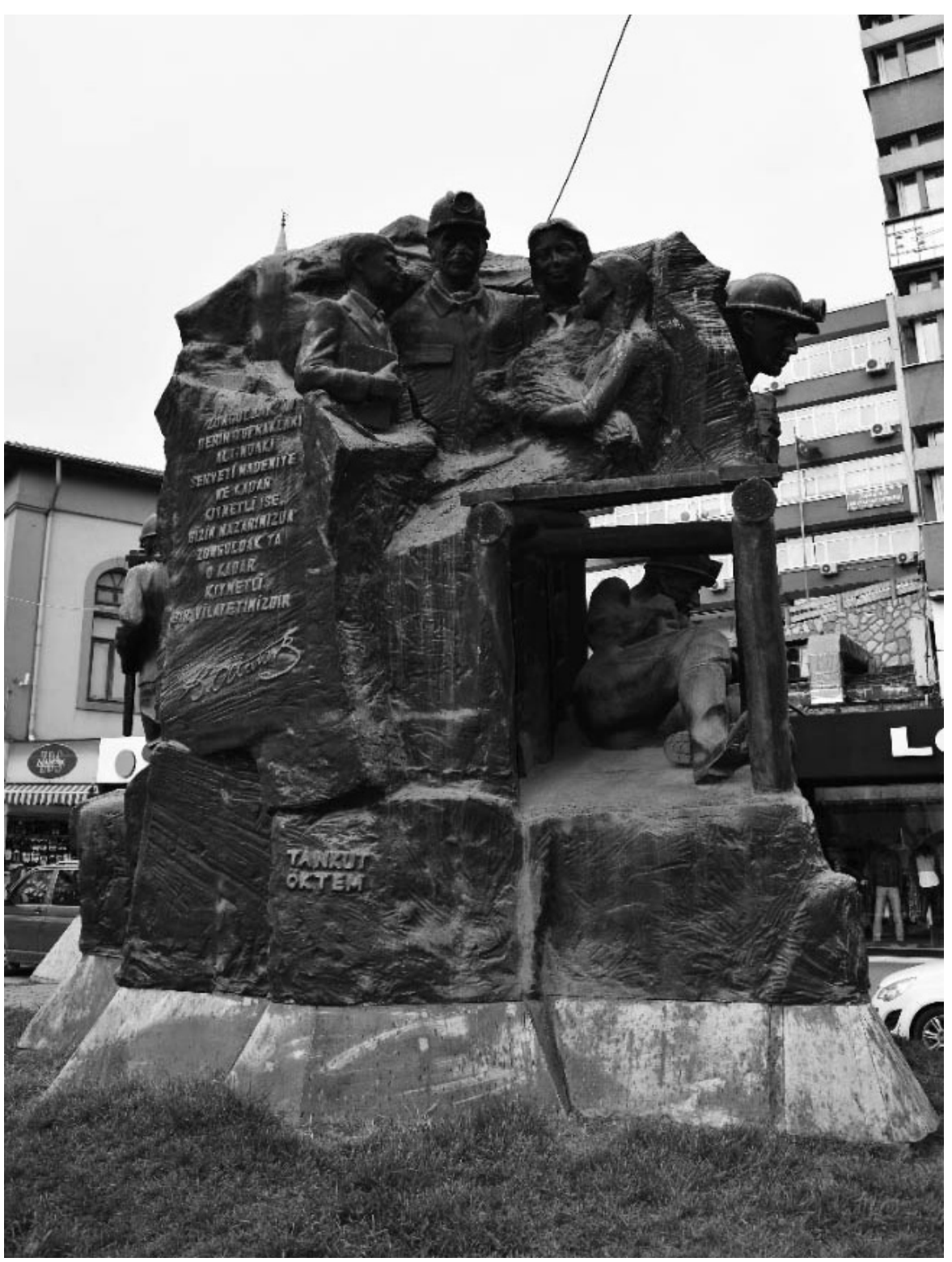

Fotoğraf 4: Tankut Öktem (1986), İşçi Anıtı, Zonguldak 
Anıtın batı cephesinin bir bölümünde işçinin ailesiyle buluşması işlenmiştir. İşçi, iş kıyafetleri içerisinde eşi ve çocuklarıyla birlikte betimlenmiştir ${ }^{5}$. Eşi iş̧̧inin solunda, çocukları ise her iki yanında sıralanmışlardır. Aile portre anlayışında yapılmıştır. Madenci ile eşi kendilerinden emin, gururla karşıya bakmakta iken, çocuklar babalarına dönüktürler. Burada madencinin iş çıkışı ailesi ile ilk buluşmasına vurgu vardır. Bu nedenle çocukların yüzleri işçi babalarına yöneliktir. Figürler iyi giyimli ve bakımlı modern bir aileyi temsil eder ve yüzleri batıya dönüktür (Fotoğraf 5). Batıya yönelen aile portrelerindeki modern giyim ve kuşamlar tesadüfi olmayıp çağdaş dünyaya yönelimi ifade eder. İşçinin hemen sağ tarafında duran oğlu, okul kıyafetleri içerisinde elinde bir kitap tutmaktadır. Kitap, aydın bir aileye göndermede bulunur. Diğer tarafta duran kız ise örülü saçları ile temiz ve bakımlıdır. Elinde bir demet çiçek tutmaktadır. Böylece madenci babanın gelişi adeta törensel bir atmosfere büründürülmüştür. İşçi, ailesi için iyi yaşam koşulları sağlamıştır. $\mathrm{Bu}$ anlatım yönüyle sanatçının klasik anlayışta anlatımcı üslubu dikkat çeker. Figürler anatomik gerçekliğe sahiptir ancak, anlatım gerçekten ziyade temsili bir yüceltme içindeki temennileri barındırır.

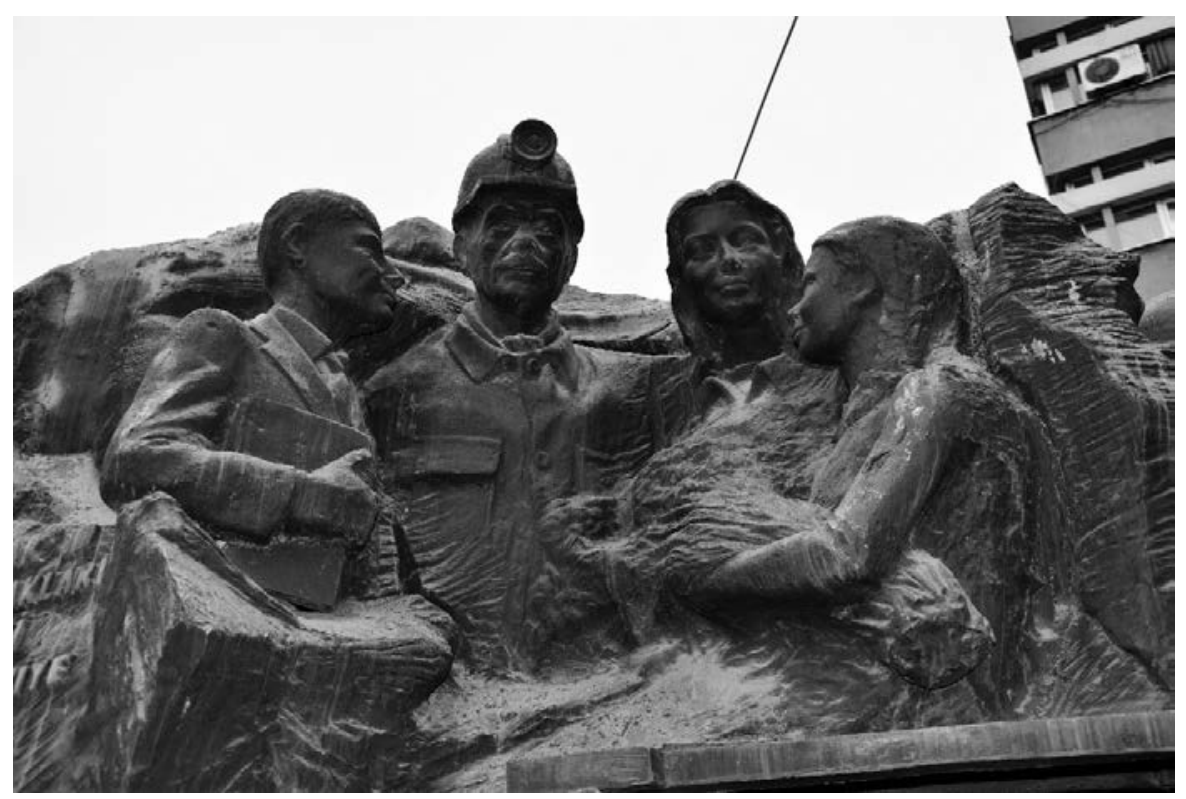

Fotoğraf 5: Tankut Öktem (1986), İşçi Anıtı, Zonguldak

Anıtın arka yüzünde elindeki kırma makinesi ile dar bir alanda uzanarak çalışan madencinin koşulları betimlenmiştir. Etrafinda oluşabilecek çökme-

\footnotetext{
5 Buradaki işçi ve ailesi portlerinde de Mehmet Tezer ve ailesi betimlenmiştir.
} 
leri önlemek için ahşap direklerle desteklenmiş bu alanda realist bir şekilde betimlenen madenci çalı̧̧maya odaklanmıştır ${ }^{6}$. Ayağıyla ahşap direklerden destek alarak elindeki makine (martopikör) ile madenin duvarındaki kömürü ç1karmaktadır (Fotoğraf 6).

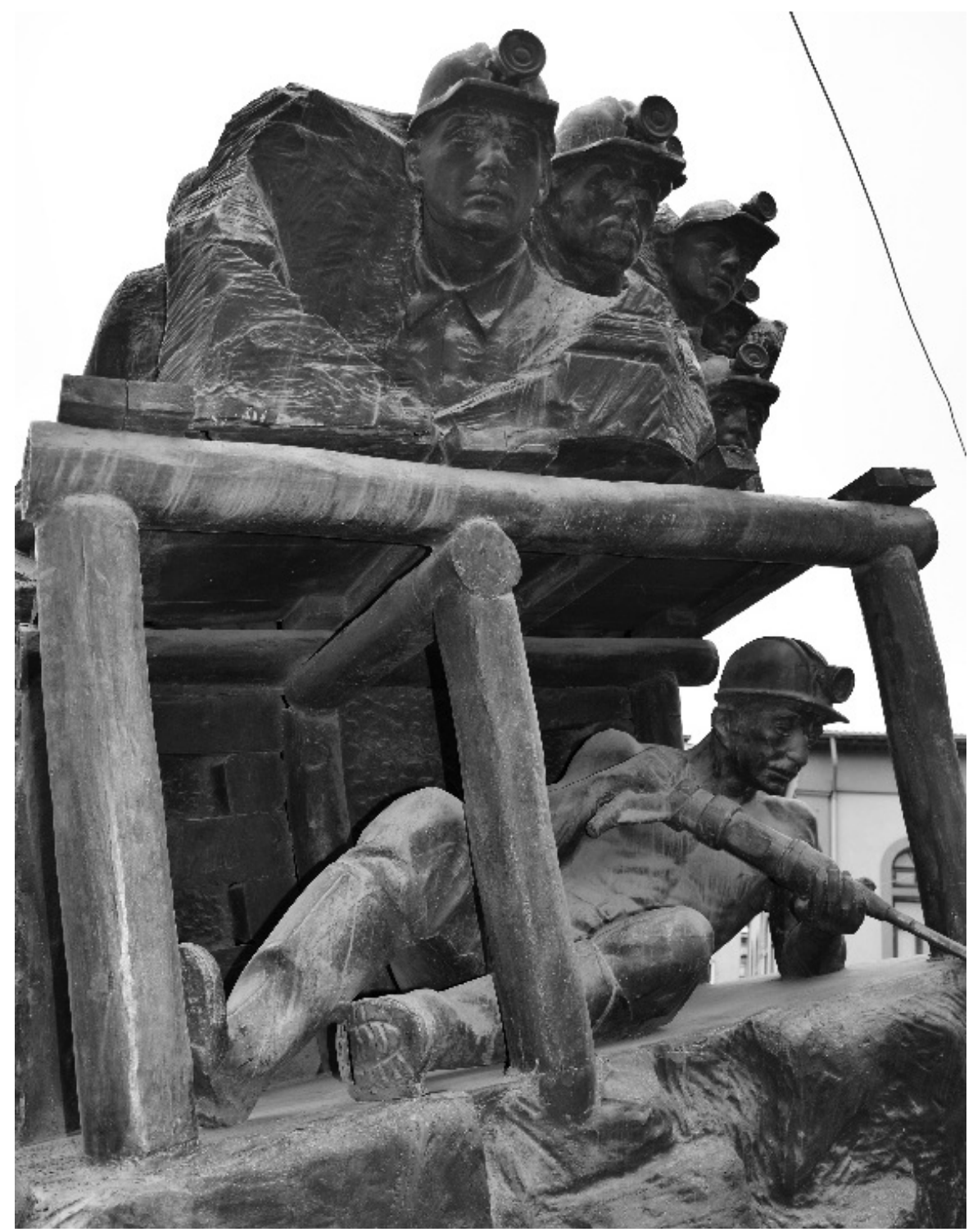

Fotoğraf 6: Tankut Öktem (1986), İşçi Anıtı, Zonguldak

6 Bu figürün modelliğini kazmacı Hamza Adıbaş adlı maden işçisi yapmıştır. 
Ahşap direklerle desteklenmiş tünelin üstünde portre şeklinde ele alınmış altı iş̧̧i de görülür (Fotoğraf 7). Bu işçiler ülkenin dört bir yanından çalışmak için buraya gelen kişilerdir. Portreler kararlı, vakur ifadeleriyle dikkat çeker. Keskin yüz hatları ile adeta üzerlerindeki yükümlülüğün farkında olduklarını gösterircesine idealize edilmiş bu portreler antik çağ heykellerini anımsatmaktadırlar.

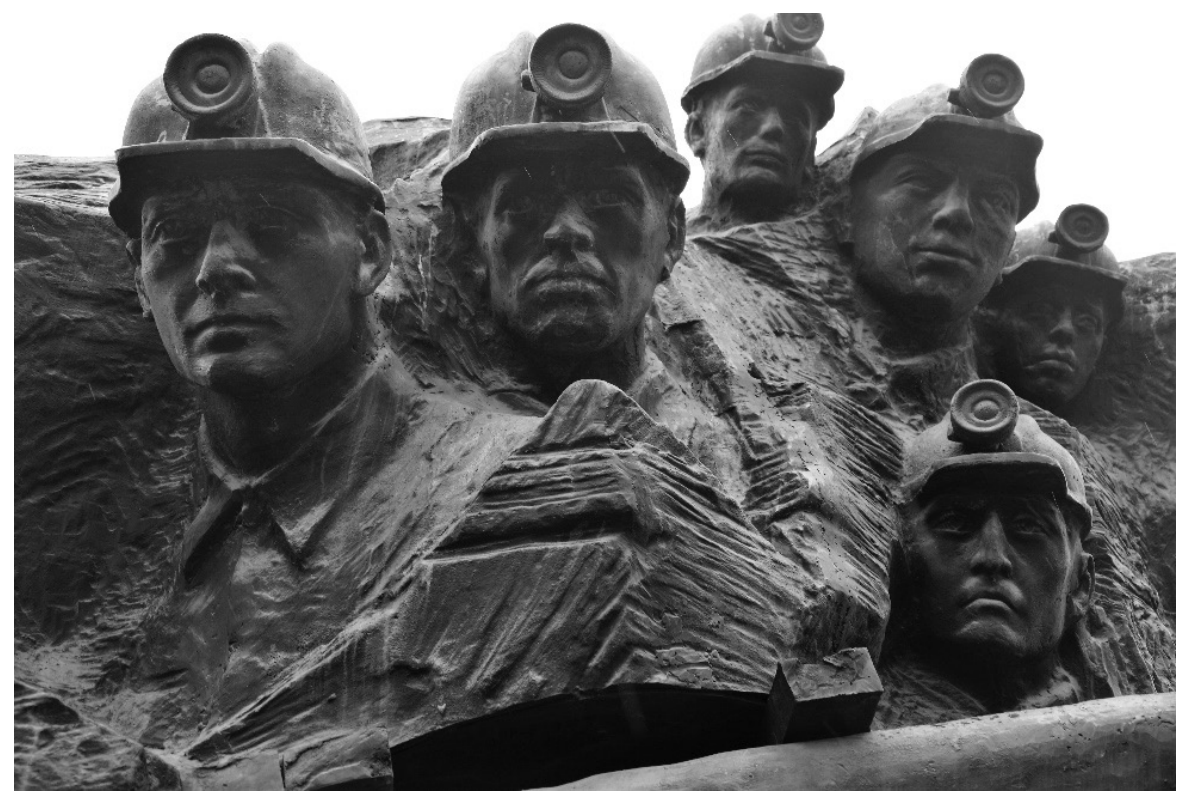

Fotoğraf 7: Tankut Öktem (1986), İşçi Anıtı, Zonguldak

Anıt sahile uzanan caddenin başındaki 1 Mayıs Bayramı'nın kutlandığı alana yaptırılmışır. Bu alan kentin merkezi noktasıdır. Anıtın batı tarafindaki köprülü kavşaktan anıta doğru uzanan yol 1 Mayıs İşçi Bayramı'nda yürüyüş güzergahıdır. Anıt bu yönüyle Zonguldak için odak noktası oluşturur. Ancak anıtın bulunduğu meydanın iki yanında konumlandırılmış binalar adeta yapıtı kavşağa sıkıştırmakta ve böylece kamusal alandaki etkisini zayıflatmaktadır. 


\subsubsection{Zonguldak Havzası Maden Şehitleri Anıtı}

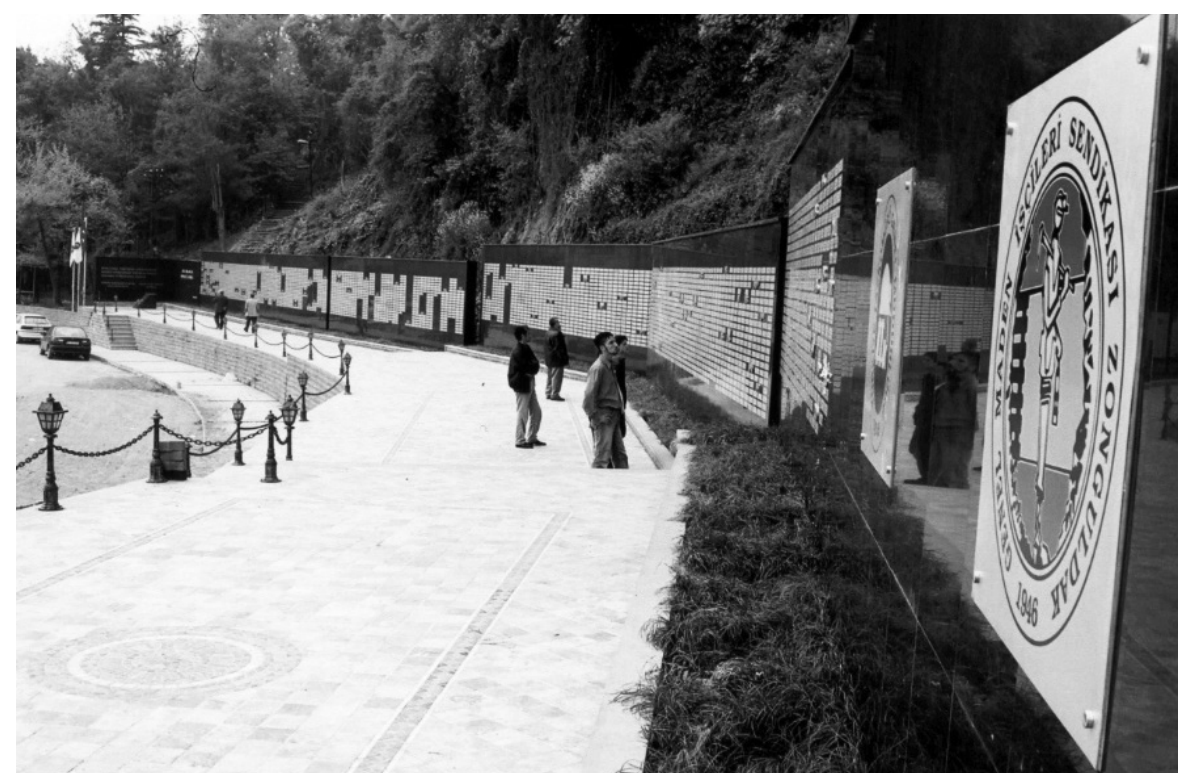

Fotoğraf 8. Zonguldak Havzası Maden Şehitleri Anıtı, (2003).

Anıt, 1911 yılından 2003 yılına değin hayatını kaybeden 4500 madencinin anısına Türkiye Taş Kömürü Kurumu ve Genel Maden İşçileri Sendikası iş birliğiyle Zonguldak Liman Caddesi üzerinde 2002 y1lında projelendirilerek 25 Mayıs 2003 yılında yaptırılmıştır. Ayrıca anıtın çevre düzenlemesi Zonguldak Belediyesi tarafindan gerçekleştirilmiştir (Fotoğraf 8).

Anıt, sekiz basamaklı yükseltiyle ulaşılan yaklaşık 100 metre uzunluğundaki 7 adet pano duvardan oluşmaktadır. Panolarda çeşitli zamanlarda hayatını kaybetmiş madencilerin isimleri yazılıdır. Bu panoların bulunduğu kısmın önünde konumlandırılmış maden ocaklarında kullanılan araçlar, anıtla bir bütünlük oluşturmaktadır. Panoların boyutları birbirlerinden farklıdır. İlk ve ikinci panolar 'L' biçiminde oluşturulmuş ve yükseklikleri diğer panolardan aşağıdadır. Bu betonarme duvarlar siyah renkte granit mermer ile kaplanmıştır. Betonarme duvarın kalınlığı 34 cm'dir. Anıt duvarının önündeki yürüyüş bandı antik traverten ve eskitme yöntemi uygulanmış antik mermer taşlarla döşenmiştir. Zeminde mermer taşların döşenmesiyle oluşturulmuş geometrik motifler yer almaktadır. Yapıtın çevre duvarı çarpma andezit taşıdır. Yapıtı oluşturan 7 mermer panodan girişteki ilk pano diğer panolara göre dik konumda yerleştirilmiştir. Panonun üzerinde anıtı yaptıran kurumların adları ve anıtın yapılış nedeni ifade edilmiştir. İkinci sıradaki siyah granit 
kaplı panonun üzerinde ise anıtın açık adı olan 'Zonguldak Havzası Maden Şehitleri Anıtı' yazılıdır. Bu iki panonun önünde üzerinde maden işçiliğini temsil eden kazma ve kırma aletlerinin sembollerini barındıran bir platform vardır. Platformu oluşturan diğer panoların üçünde ise maden ocaklarındaki kazalarda hayatını kaybeden madenci adlarının yazılı olduğu levhalar siyah granit mermere yapıştırılmıştır. Siyah granit mermer maden ocaklarının duvarlarını simgeler. İsimliklerin yanı sıra madencilerin hayatlarını kaybettikleri yıllar da pirinç malzemeden rakamlarla belirtilmiştir. Anıtın son iki panosu üzerinde, panolara hâkim, büyükçe yaptırılmış Türkiye Taş Kurumu Genel Müdürlüğünün ve Genel Maden İşçileri Sendikası'nın amblemleri yer almaktaydı. Günümüzde bu iki amblem de kaldırılmıştır (Fotoğraf 9).

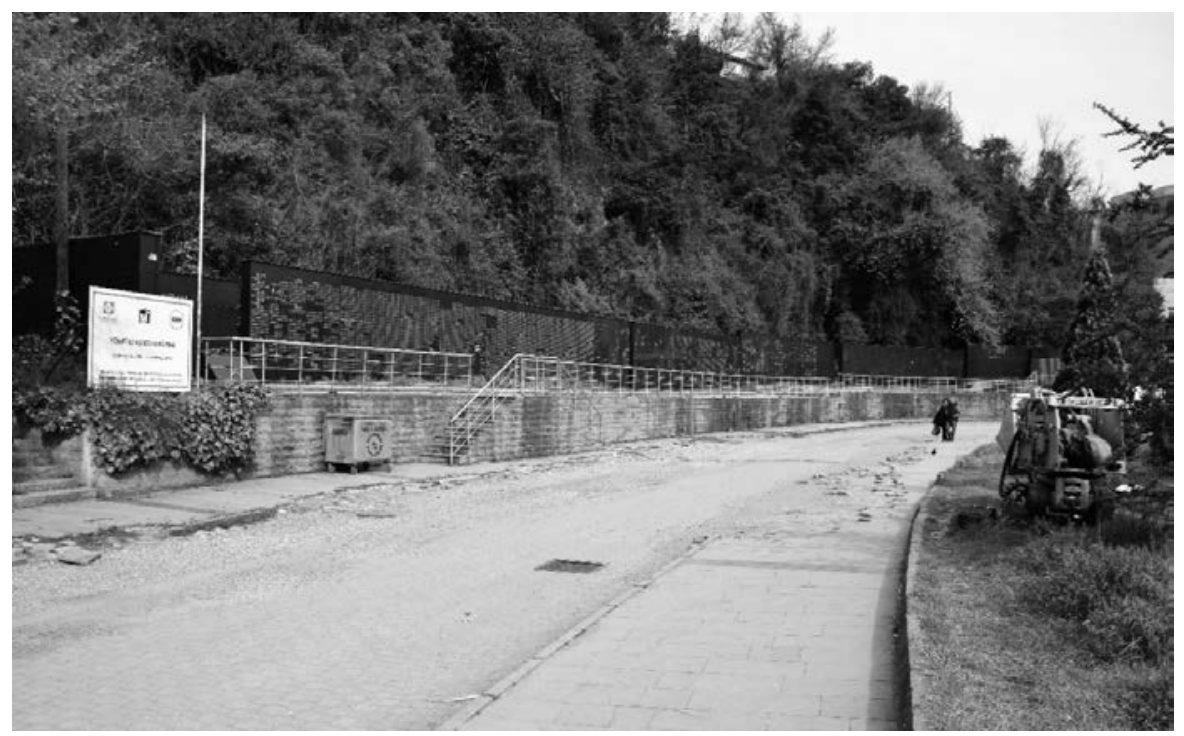

Fotoğraf 9. Zonguldak Havzası Maden Şehitleri Anıtı, (2003).

Anıtın çevre düzenlemesi sırasında maden ocaklarında kullanılmış bazı araç gereçler de tüm anıt alanını ikiye bölen yolun denize bakan yönünde belirli aralıklarla yerleştirilmiştir. Anıt sahil yolu üzerinde yer alır ve dalga kıranla desteklenmiş küçük bir körfeze bakar. Dalgalardan uzakta olan anıt çevre düzenlemeleri ve anıta uzanan sahil yolunun kullanışlı olmasına bağlı olarak kamusal alanda sanata hizmet eder. Gezinti yolunun neredeyse son durağında yer alan anıt ve anıtın çevresi etki alanını bahsettiğimiz bu unsurlara bağlı olarak artırır veya azaltır?.

7 Bu anıt Hacettepe Üniversitesi Türkiyat Araştırmaları Dergisi’nin aralık ayında 27. sayısında yayımlanacak olan 'Bir Anıtın Enstalasyona Dönüşümü: Zonguldak Havzası Maden Şehitleri Anıtı' başlıklı makalede de işlenmiştir (Oral 2017). 


\subsubsection{Madenci Heykeli}

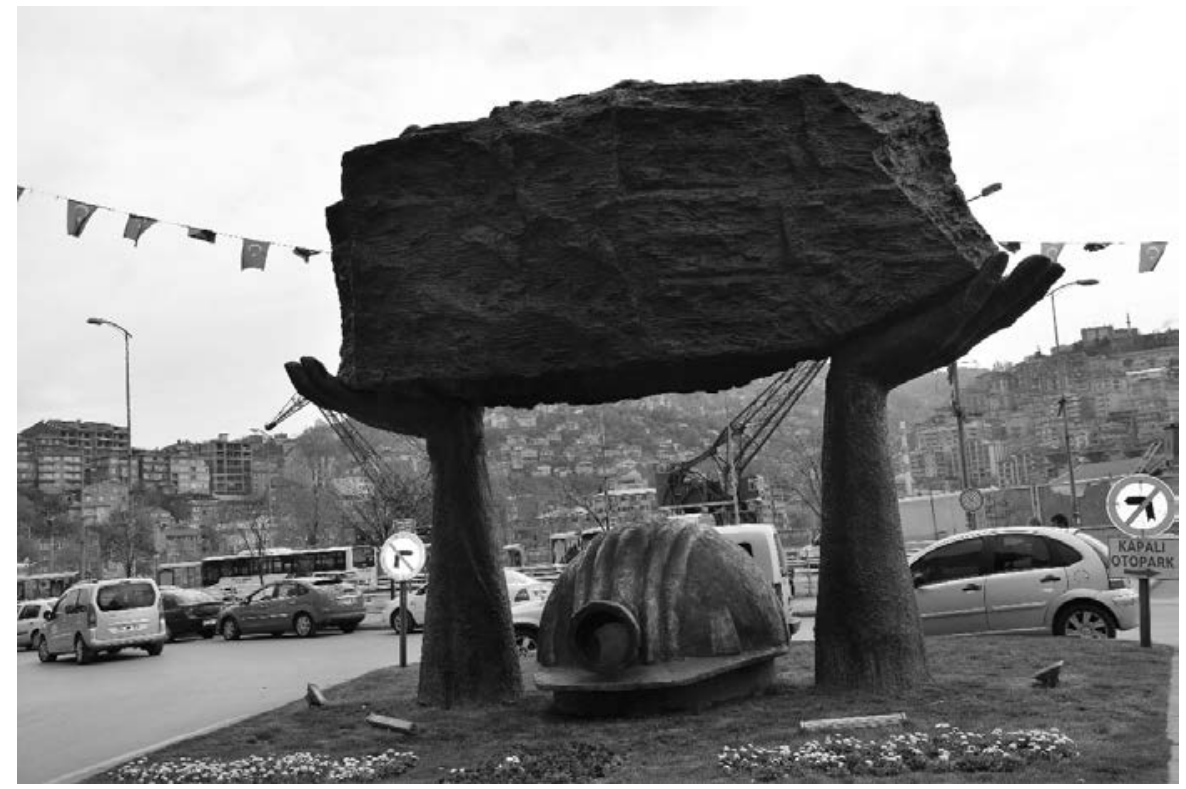

Fotoğraf 10. Artil Sanat Atölyesi (2013), Madenci Heykeli, Zonguldak

Anıt heykel 8 Kasım 2013 tarihinde Artil Sanat Atölyesi'nde çalışmalarda bulunan bir grup heykeltıraş tarafindan yapılarak 'Uzun Mehmet'i Anma ve Kömür Günü’nde' tamamlanmıştır. Anıt, metal konstrüksiyon üzerine cam elyaf polyesterden yaptırılmıştır. Heykelin yüksekliği 4,60 eni 6.90 metredir. Madencinin elinde tuttuğu kömür 3 metre yüksekliğinde 6,5 metre kenar uzunluğundadır (Fotoğraf 10).

Heykelin yapım sürecinde çok sayıda çamurdan model yapılmış ve yapılan modeller içerisinden anıtın bu biçimine karar kılınmıştır ${ }^{8}$. Anıt heykelde; boynundan aşağısı toprak altında betimlenen, iki eliyle yukarıya doğru kaldırdığı kömür parçasını tutmakta olan bir işçi simgesi yer alır. İşçinin sadece bareti ve dirseklerinden itibaren kolu ile elleri görülmektedir. Gövdesi toprağa gömülüdür. İşçinin başındaki baret ve önünü aydınlatan feneri dikkat çeker. Böylece baret ile toprak arasında kalmış şekilde konumlandırılan madencinin yüz ifadesine vurgu yapılmamıştır. Madencinin baretindeki fener ile anıtın ilk yapımında geceleri şehrin bu noktasının aydınlatılarak maden ocağının temsili amaçlanmış ancak sonradan kullanılmamıştır.

8 Anıt ile ilgili üç model belediye yetkililerine sunulmuştur. Bunlar arasından belediye yetkilileri tarafından günümüzdeki model tercih edilmiştir. 
Nesnelerin gerçek formlara yakın olmaları ve klasik yaklaşımda ele alınmaları anıttaki realist betimlemeyi idealize ederek ortaya koyar. Anıtta zor koşullar altında çıkarılan maden ve madendeki iş̧̧inin harcadığı emek işlenmiştir. Maden ocaklarında kömürün yukarıya taşınması dönemin teknolojik gelişmeleri ve ülkedeki yeterliliklere bağlı olarak değişkenlik gösterir. Ancak, gerçekte taşınma yöntemi olmayan doğrudan el üstündeki büyükçe kömür parçası tamamen temsilidir, bu taşıma biçimi iş̧̧i emeğine, kömür parçasının büyüklüğü ise madenin ne kadar değerli olduğuna vurgudur.

Yer altından çıkan mitolojik bir kahraman gibi yeryüzünde beliren madenci figürünün toprağın altına gömülü gövdesi ile betimlenmesi postmodern sanat anlayışındadır. Bu heykele benzeyen anıt heykeller modern Avrupa'da 1960'l1 yıllardan beri görülmektedir. Londra'daki 'Yüzen Adam Heykeli' (Foto 11), Almanya'daki Yıkanan Kadın Heykeli (Die Badende), Amsterdam'daki 'Kemancı Heykeli' (Foto 12), Washington D.C. 'Uyanış' adlı heykel çevreleriyle oluşturdukları güçlü plastik etki ve konumlandırıldıkları yer ile bütünlük oluşturmaktadırlar. Madenci Heykeli'ndeki bu anlatım, Avrupa'daki bu kompozisyona sahip benzer anıt heykellerin kamusal alanda yarattı̆̆1 etkiye sahip değildir. Heykel, oluşturduğu güçlü plastik etkiye zit bir yerde konumlandırıldığından bulunduğu yer ile yeterince bütünlük oluşturmaz. Kent dokusunun zayıflı̆g 1 da bunda önemli etkendir.

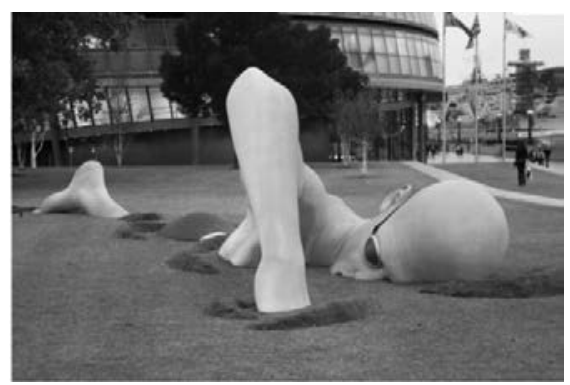

Fotoğraf 11. Londra'daki Yüzen Adam Heykeli

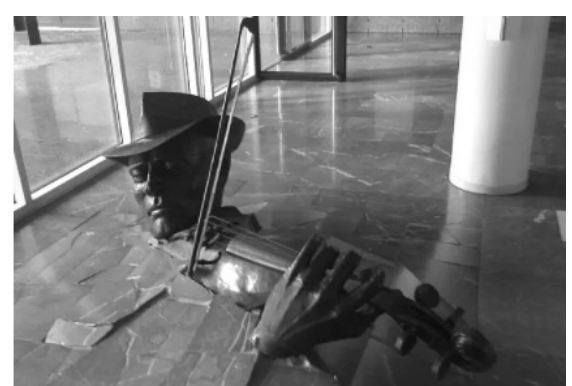

Fotoğraf 12. Amsterdam'daki Kemanc1 Heykeli

(https://onedio.com/haber/ilginc-heykeller-599307 Erişim Tarihi: 15.05.2017) 


\subsubsection{Ereğli Uzun Mehmet Anıtı (Madenci Heykeli)}

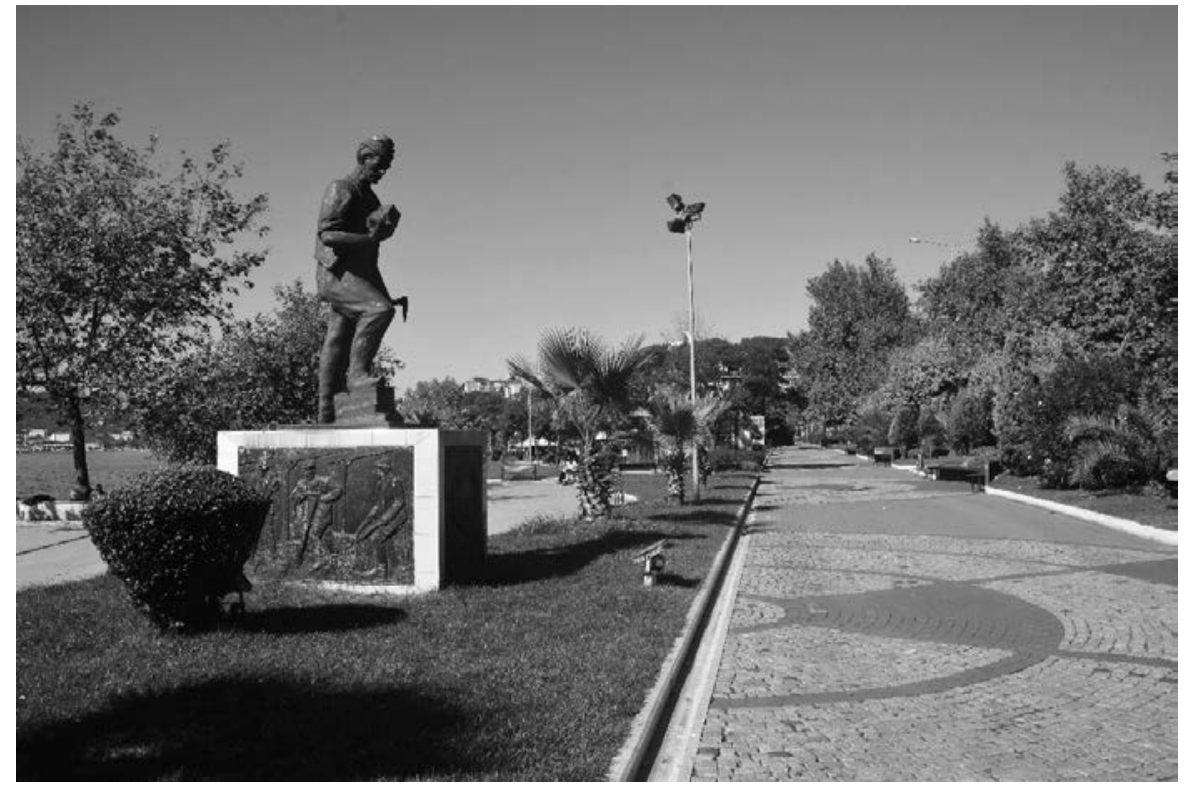

Fotoğraf 13. Aslan Başpınar (1932), Ereğli Uzun Mehmet Anıtı (Madenci Heykeli)

Zonguldak'ın Ereğlii ilçesindeki Madenci Heykeli, sahildeki yüksekçe bir platform üzerine yerleştirilmiştir. Heykel, Uzun Mehmet'in askerden sonra döndüğü memleketinde kömür madeni parçalarını bulduğu kabul edilen tarihin yıldönümünde (8 Kasım 1932) Uzun Mehmet anısına Heykeltıraş Aslan Başpınar'a yaptırılmıştır (Fotoğraf 13).

Heykel, üzerindeki yöresel kıyafetlerle bir elinde kazmas $1^{10}$ diğer elinde bulduğu kömür parçası ile betimlenmiş bir erkek figürüdür. Uzun Mehmet başı sarıll, üzerinde cepken ve gömlek, belinde kuşak, şalvar tarzı bir pantolon ve çarığa benzer ayakkabı ile görülür (Fotoğraf 14).

9 Ereğli'de bu anıt heykel dışında Uzun Mehmet anısına yaptırılmış bir anıt daha bulunmaktadır. Anıt 2016 yılında tamamlanarak açılmıştır. Korkuluklarla çevrelenen üç basamaklı bir platform üzerinde maden ocağı duvarını temsil eden taş dizimli yüksek bir kaide üzerine anıtsal nitelikte gaz lambası yerleştirilmiştir. İşçi temsilinde öne çıkan gaz lambası anıtta ana simge olarak betimlenmiştir. Böylece maden şehitlerini anma törenleri için ek bir alan yaratılmıştır.

10 Kazması çeşitli tarihlerde birkaç kez kırılmıştır. Neden kırıldığı belirlenememiş olunsa da her seferinde yeniden bir kazma kullanılmıştır. 


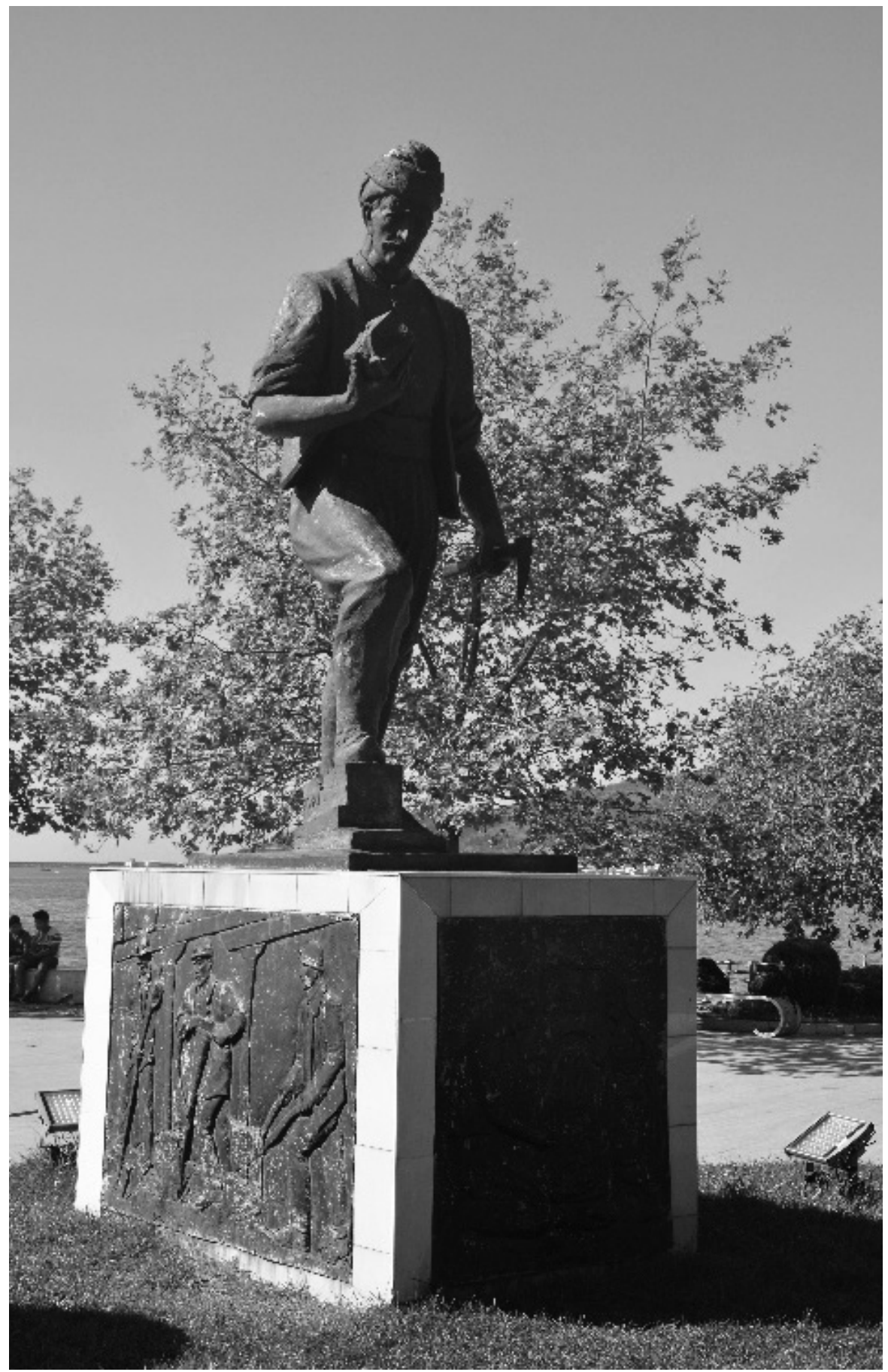

131
हे
$\dot{ }$

Fotoğraf 14. Aslan Başpınar (1932), Ereğli Uzun Mehmet Anıtı (Madenci Heykeli) 
Heykel, Uzun Mehmet'in kömür parçasını bulduktan sonraki anı temsil eder. Uzun Mehmet elindeki kömüre bakarken yürür halde betimlenmiştir. Güçlü bir devinim söz konusudur. Figürün sağ ayağı bir adım öndedir. Sağ ayağını bastığı taş, bulunduğu coğrafyanın engebeli arazisini anıt heykele taşır. Heykeltıraş adını Uzun Mehmet'in ayağını bastığı taş kaideye kazımıştır. Heykelin konumlandırıldığg kaidenin ön yüzünde Uzun Mehmet ve annesi ocak başında kömür parçalarını ateşe atarken görülmektedir. Uzun Mehmet yanmakta olan ocağın önünde diz çökmüş vaziyette otururken bir sepette yer alan kömür parçaları arasından birini elinde tutmakta, annesi ise bir elinde kömür parçası tutarken diğer eliyle ağzını kapatmış şekilde betimlenmiştir. Ağzın el ile kapanması yöre kadınlarının şaşkınlık duyduklarında gösterdikleri tepkidir (Fotoğraf 15).

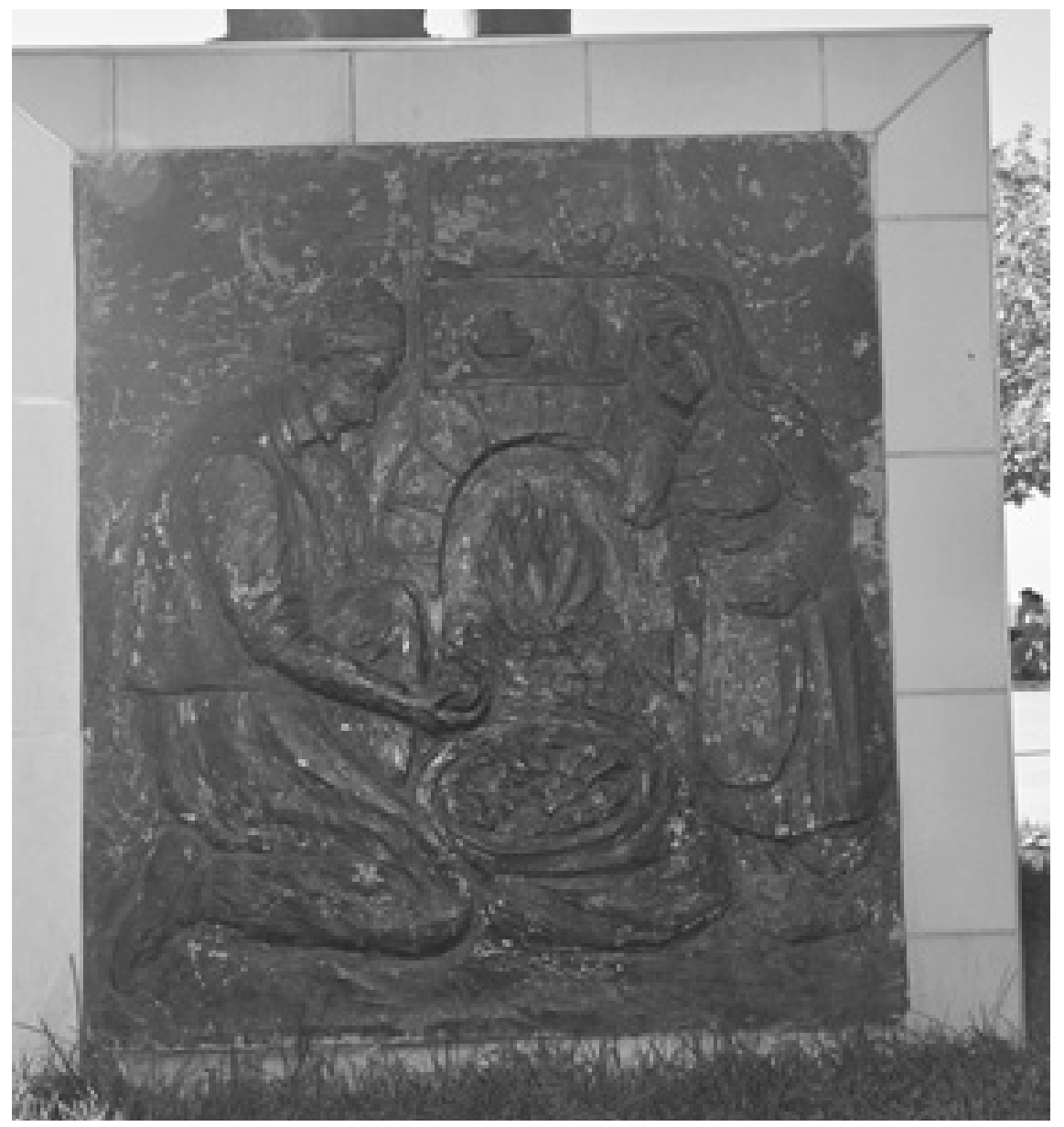

Fotoğraf 15. Aslan Başpınar (1932), Ereğli Uzun Mehmet Anıtı (Madenci Heykeli) kaidesi detay1 
Kaidenin batı cephesinde maden ocağından kömür çıkarmak için çalışmakta olan üç farklı işçi, ahşap direklerle desteklenen ocağın içinde üçlü kompozisyon oluşturacak şekilde klasik çizgiler içinde gösterilmektedir. Bunlardan sol taraftaki kürekle çalışan bir işçiyi, ortadaki kırma makinası ile çalışan işçiyi, sağdaki ise el arabası ile kömür taşıyan işçiyi betimlemektedir. Betimlemeleri içeren rölyef anlatımcı bir dilde realisttir (Fotoğraf 16).

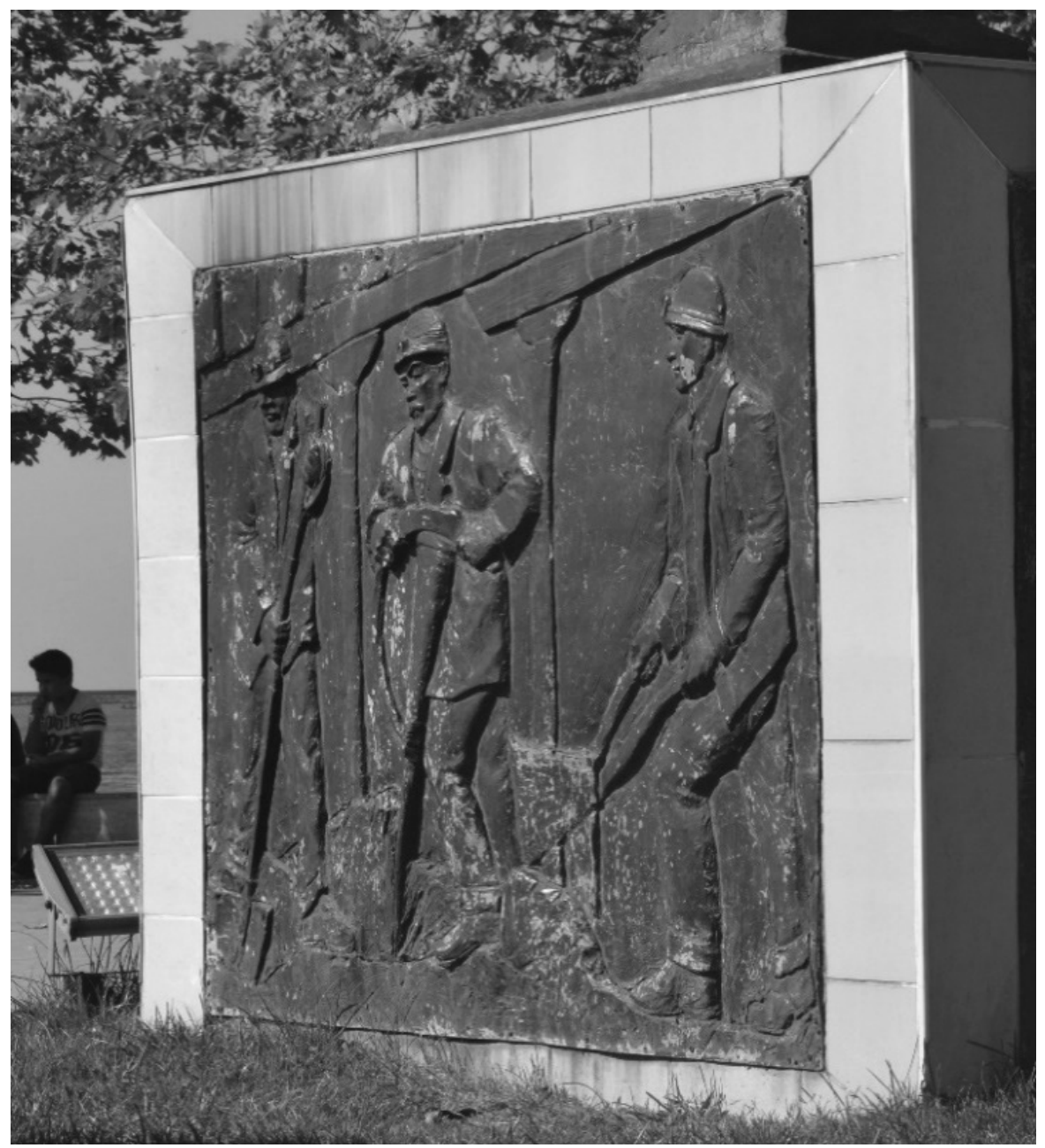

Fotoğraf 16. Aslan Başpınar (1932), Ereğli Uzun Mehmet Anıtı (Madenci Heykeli) kaidesi detayı

Kaidenin doğu cephesinde ise maden ocağ tünelinde üç işçi görülmektedir. İşçilerden biri kömür vagonunu itmekte, diğer bir işçi elindeki kazmayla kömürü parçalarına ayırmakta, bir diğeri ise eline aldığı büyükçe bir kömür par- 
çasını taşımaktadır (Fotoğraf 17). Kömürün bulunması ve çıkarılması süreci anıtın kaidesinde adeta bir belgesel niteliğinde işlenmiştir.

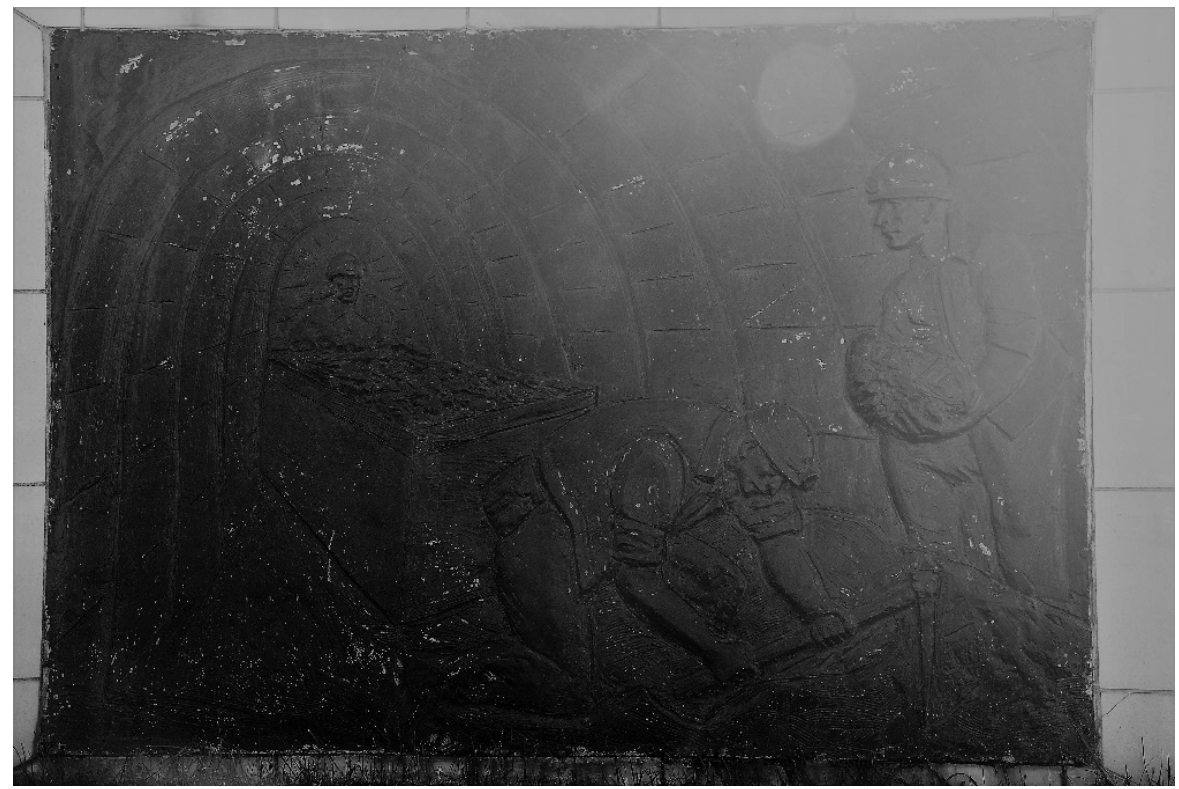

Fotoğraf 17. Aslan Başpınar (1932), Ereğli Uzun Mehmet Anıtı (Madenci Heykeli) kaidesi detay 1 


\subsubsection{Kozlu Madenci Heykeli}

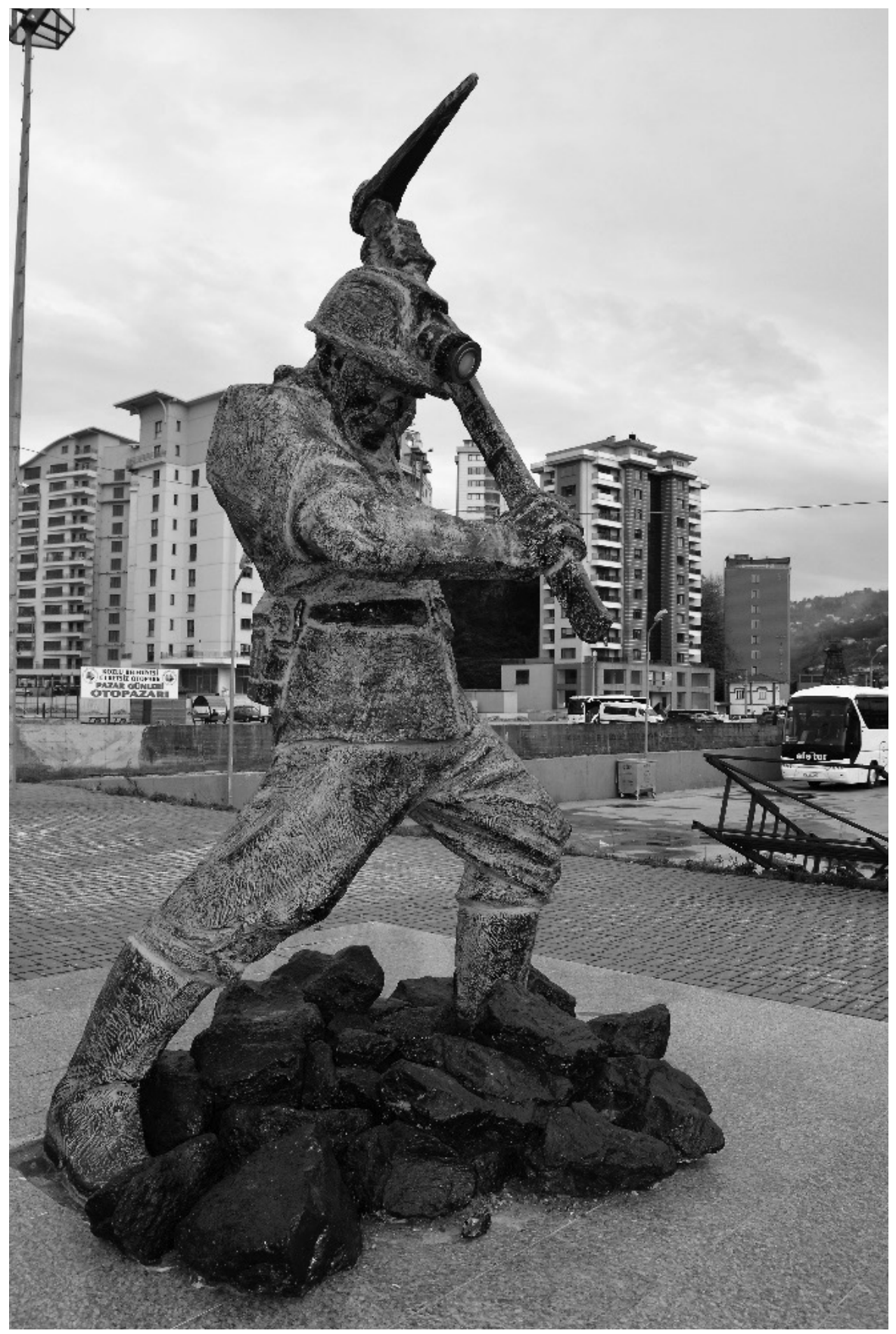

Fotoğraf 18. Metin Yurdanur (1991), Madenci Anıt1, Polyester, Kozlu-Zonguldak 
Anıt, 1991 yılında heykeltıraş Metin Yurdanur'a yaptırılmıştır ${ }^{11}$. Heykel 3,30 m yüksekliğinde, 190 x88 cm ölçülerinde dikdörtgen bir kaide üzerine yapılmıştır. Malzemesi polyesterdir (Fotoğraf 18).

Anıttaki figür bir madenciyi temsil eder. Madenci, iş elbisesi ile elbiseyi tamamlayan fenerli baret ve elindeki kazmayla betimlenmiştir. Figürdeki kıvrımlar kömür çıkarmaya odaklanmış madenciyi idealist üslupta gerçekçi anlayışta betimlemektedir.

$\mathrm{Bu}$ anlatım temsili işçi figürünün yüzünde keskin bir ifadeyle buluşur. İşçinin ve elbisesinin keskin hatları güç, irade, emek vurgusunu ve işçinin yere sağlam basan ayakları ile kararlı ifadesini tamamlar. Madencinin ayaklarının çevresinde bulunan kömür parçaları maden ocağına atıfta bulunan tek simgedir. Burada kullanılan kömürler gerçek kömür parçalarıdır ${ }^{12}$.

Heykel, yere son derece sağlam basan ayakları, kararlı yüz ifadesi ile işine odaklanmış ve kömürü çıkarmak için savurduğu kazmasıyla betimlenmiş işçiyi gösteren bir kompozisyon oluşturmaktadır. Böylece ortaya çıkan güçlü devinimle kömür çıkarırken yılgın görünmeyen bir madenciye atıf yapılmaktadir.

136 Anıt, Kozlu ilçe girişinde kamuya açık bir alanda betimlenmiştir. Heykeltıraş, madenciyi dar alanda maden ocağının duvarlarındaki kömür kütlelerine hamle yaparken betimlemek istemiştir. Heykelde simgelenen madencinin vücut kıvrımlarına bakıldığında dar alanda (maden ocağında) çalıştığı anlaşılmaktadır. Ancak, anıtta görünür şekilde bir maden ocağına yer verilmemesi yerdeki kömür parçalarına vurur görünen rahat hareket alanına sahip madencinin vücudundaki kıvrımları kamusal alanda anlaşılmaz kılmaktadır. Sanatçının heykelde anıtsal bir duruş ve güçlü bir devinim ortaya koyma kaygısıyla madenciyi idealize etmeyi öncelikli düşünmesi bunun muhtemel nedenlerinden biri olarak değerlendirilmektedir.

\subsection{Karabük İşçi Anıt Heykelleri}

Karabük anıt heykel örneklerinin çeşitliliği bakımından Zonguldak'ın gerisinde kalmıştır. Ancak kent çeşitli dönemlerde az sayıda da olsa sanat etkinliklerine ev sahipliği yapmıştır. Bunlardan en dikkat çeken etkinlik Metal Heykel Sempozyumu'dur. 2009 yılında Karabük Valiliği, Mimar Sinan Üni-

11 Aynı heykel Ankara ilinde de yine Metin Yurdanur tarafından kalıp alınarak gerçekleştirilmiştir.

12 Buradaki kömür parçaları kimi zaman yerlerinden sebebi tam olarak bilinmeyen nedenlerden alınmakta ya da çalınmaktadır. Her seferinde yeniden kömür parçaları buraya konulur. 
versitesi ve Kardemir iş birliği ile gerçekleştirilen etkinlik sonrasında sanatçılar tarafından yapılan sekiz heykelin ${ }^{13}$ şehrin çeşitli noktalarında sergileneceği belirtilmiş ancak bu sanat etkinliği sonraki yıllarda sürdürülmemiştir.

Kentte işçi konulu iki anıt heykel vardır. Bunlardan İşçi Heykeli sadece işçi temsilini öne çıkarırken, Atatürk Anıtı sosyo-kültürel özellikleri içeren birçok figürün arasındaki iş̧̧iyi de ele alır.

\subsection{1 İşçi Heykeli}

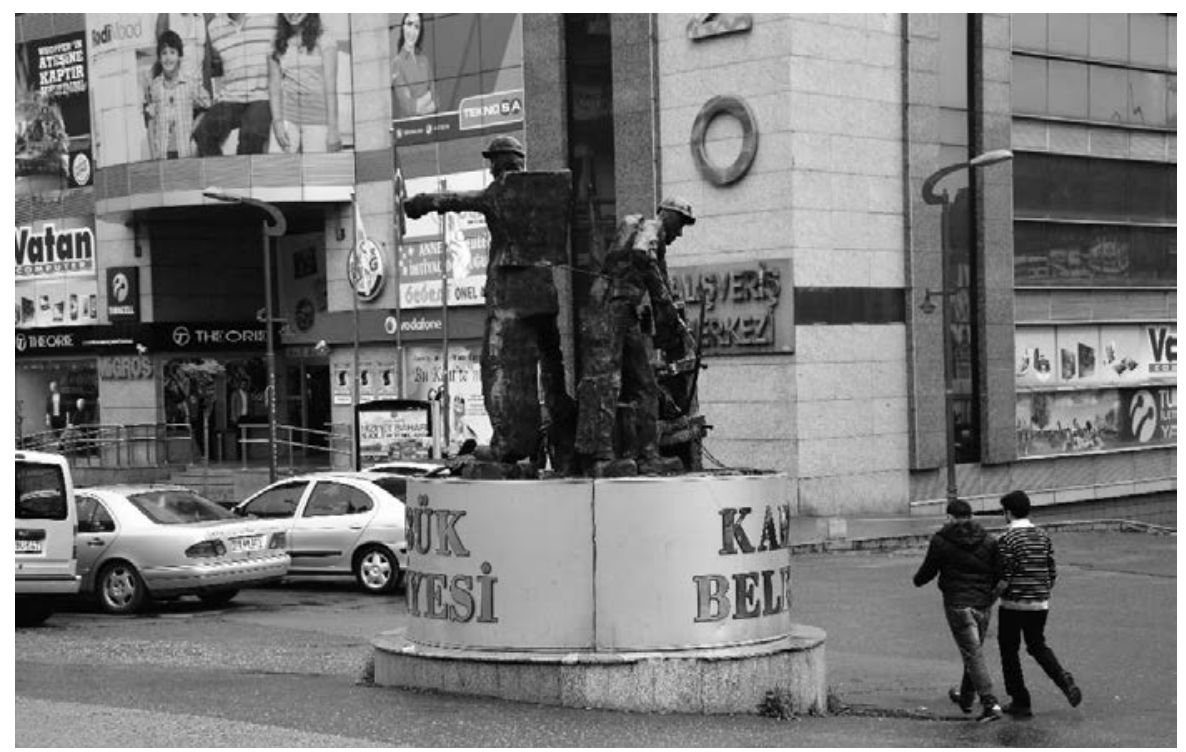

Fotoğraf 19. Ercüment İlhan (2007), İşçi Anıtı, Karabük

Heykeltıraş Ercüment İlhan'ın eseridir. Anıt, kent merkezinde ana yolların kesiştiği noktada silindirik yüksek bir kaide üzerinde konumlandırılmıştır. Kent dokusunun zayıllı̆̆ 1 , kültürel ve sanatsal bilincin yetersizliği gibi etkenler anıt heykelin deformasyonuna neden olsa da beş farklı yolun buluştuğu bir noktada olması nedeniyle heykelin kamusal sanata etkisi güçlüdür (Fotoğraf 19).

Anıtta iki sanayi işçisinin fabrikadaki herhangi bir çalışma anı betimlenmiştir. Figürlerin sanayi işçisi olduklarını gösteren kıyafetleri ve bunu tamamlayan başlarındaki baretleri vurgulanmıştır. Bu belirginlik işçilerin ifadelerinde ve vücut konturlarında geometrik çizgilerle ifade bulmuştur (Fotoğraf 20, 21).

13 Heykellerin bir kısmı Karabük Üniversitesi kampüsünde muhafaza edilmektedir. 


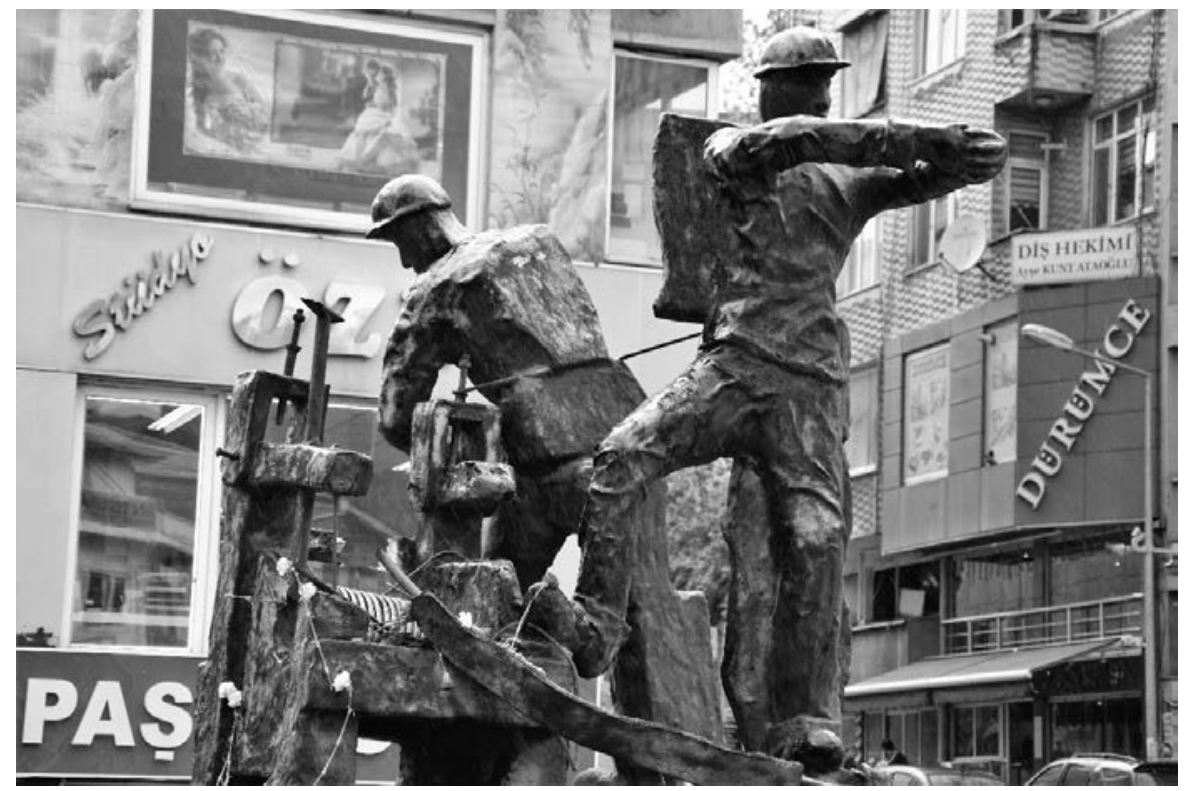

Fotoğraf 20. Ercüment İlhan (2007), İşçi Anıtı, Karabük

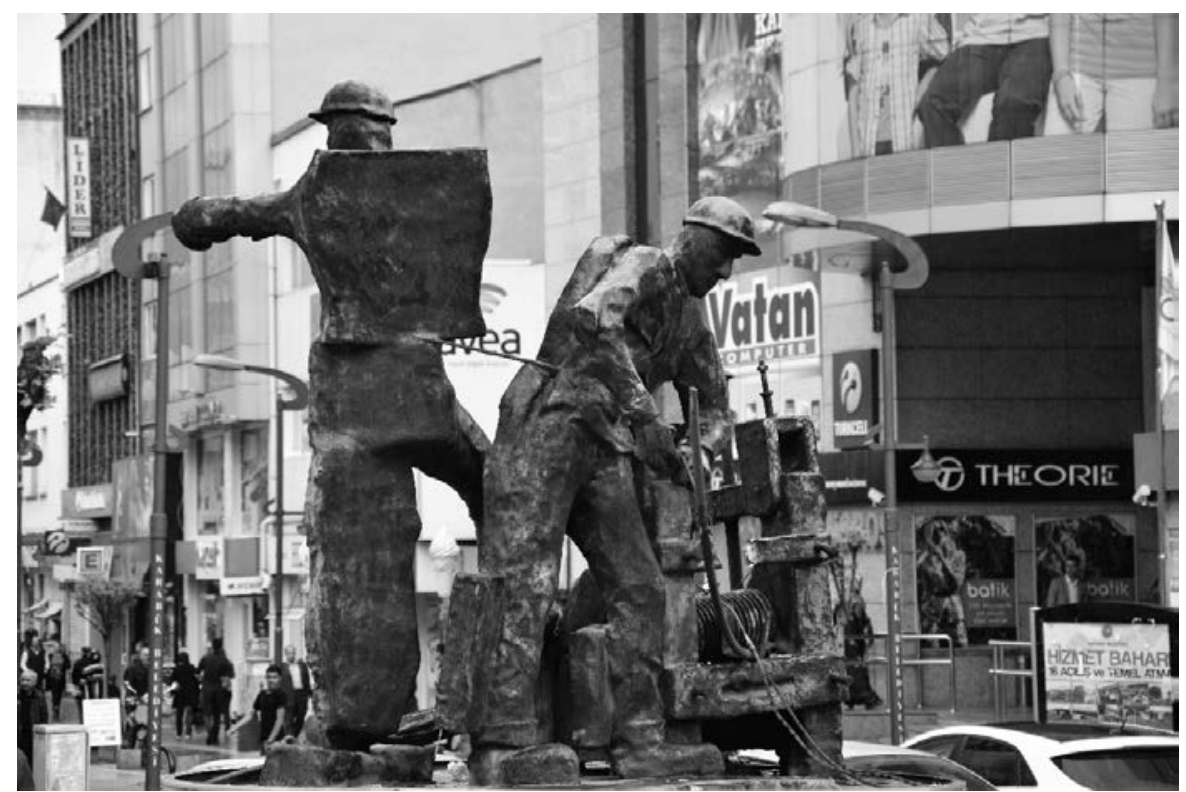

Fotoğraf 21. Ercüment İlhan (2007), İşçi Anıtı, Karabük

Ülkemizde kamusal alanda sergilenen heykellerin birçoğunda realist ya da idealist bakış açısı öne çıkarken, bu çalışmada Geç Empresyonist etkide Kübist yaklaşım öne çıkmıştır. Avrupa sanatında çok daha önce görülmeye başlayan bu yaklaşım anıtta da görülmektedir. Kübizmin biçimsel yaklaşımlarına 
da sahip olan geometrik anlatım dili bu heykele hakimdir. Çizgileri ve biçimleri basitleştirilmiş geometrik bir anlatım içeren heykelin malzemesi işçilerin çalıştıkları sanayi alanına uygun olan demir-çelik konstrüksiyondur.

\subsubsection{Atatürk Anıtı}

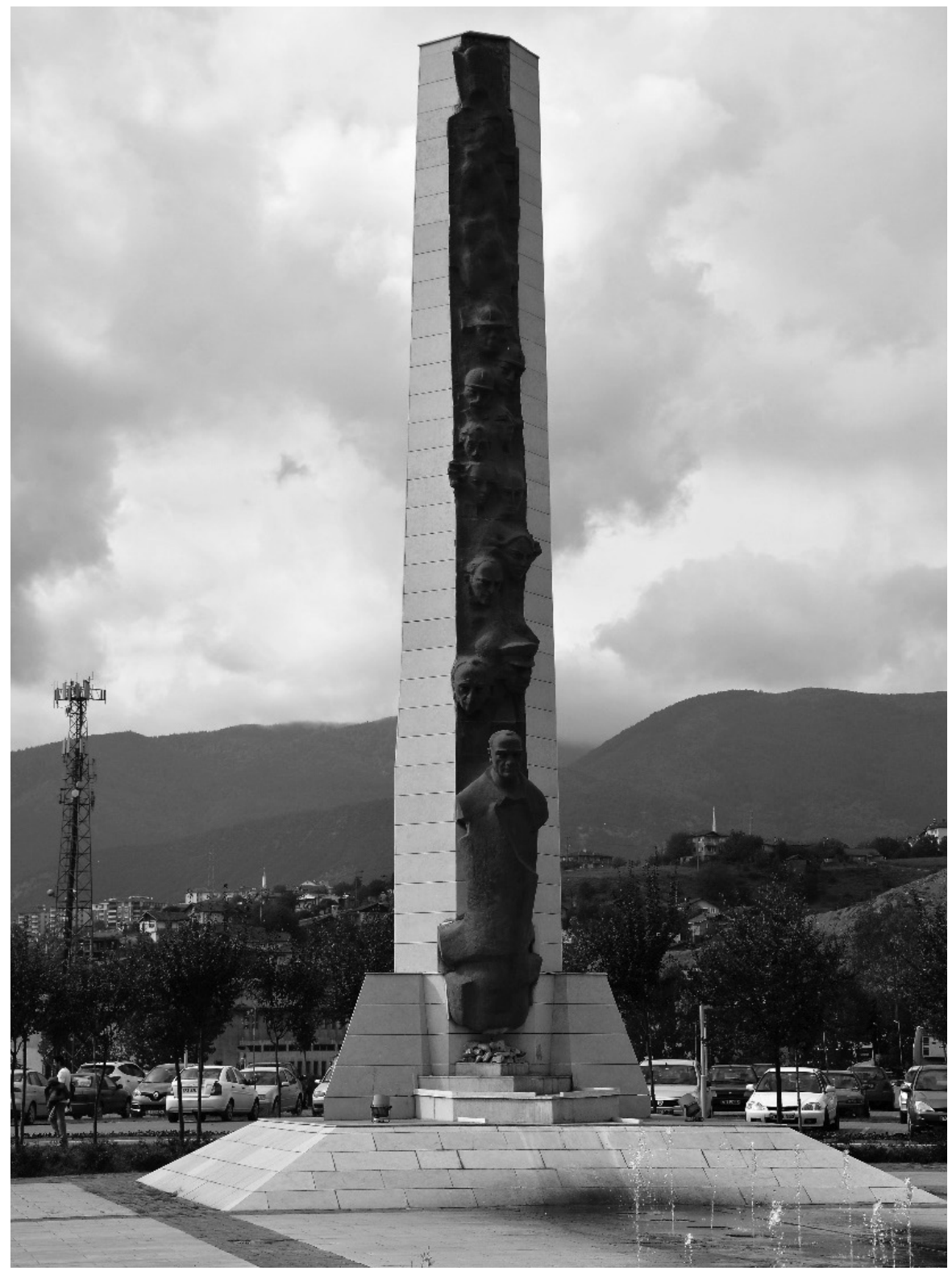

Fotoğraf 22. Ziyatin Nuriyev-Ümit Öztürk (2000), Atatürk Anıt1, Karabük 
Anıt heykel, Mimarlar M. Sinan Genim, Belma Barı̧̧ Kurtel ile Heykeltıraşlar Ziyatin Nuriyev ve Ümit Öztürk tarafindan 1999-2000 yıllarında yapilmıştır.

Karabük Valiliği önünde konumlandırılan anıt 2011 yılında çevre düzenlemesi nedeniyle bulunduğu yerden kaldırılmış, bunun üzerine Karabük Üniversitesi'nin 2011 y1lındaki yönetimi tarafından Rektörlük binasının önündeki alana yerleştirilmiştir (Fotoğraf 22).

Yapıt işçi temsilini öne çıkaran bir anıt değildir. Bu anıt Cumhuriyet'in kuruluşuna vurgu yapan, Cumhuriyet değerlerini şahıslar üzerinden aktaran bir önceliğe sahiptir. Ancak anıtın gerçekleştirildiği kentin dokusunun merkezinde yer alan işçi de anıtta temsil edilmiştir (Fotoğraf 23). Böylece Cumhuriyet'in değerleri kentin ekonomik ve toplumsal sınıflarına vurguyla özdeşleştirilmiştir.

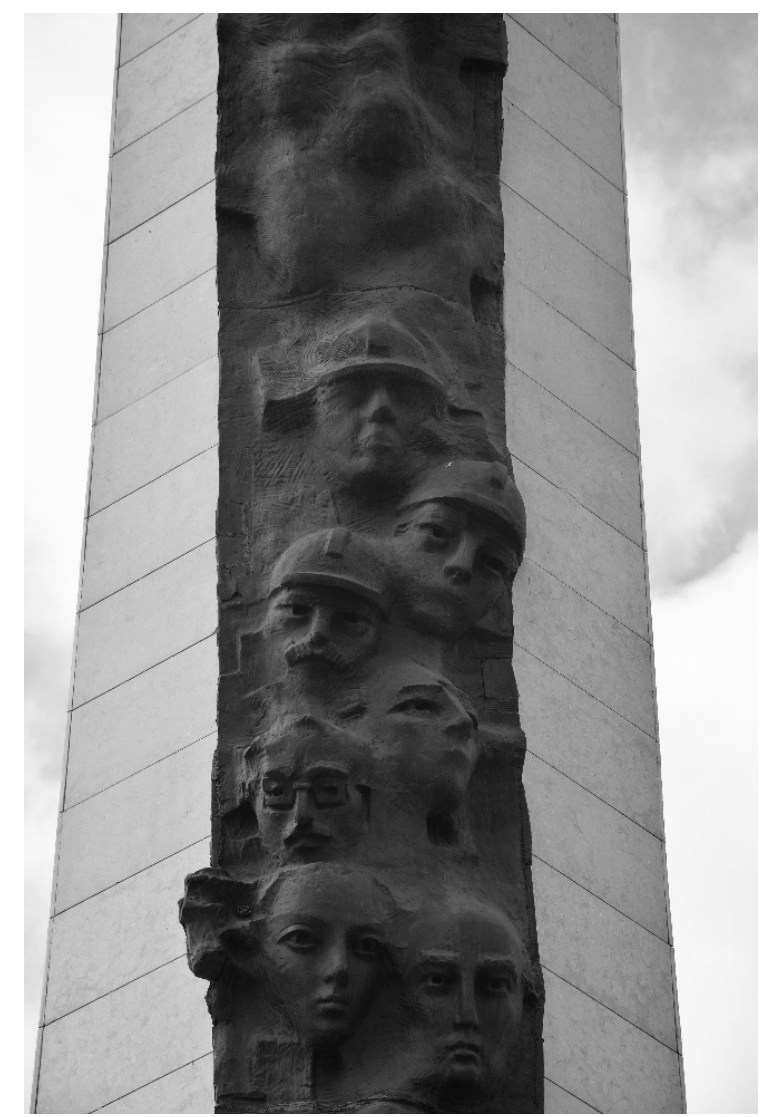

Fotoğraf 23. Ziyatin Nuriyev-Ümit Öztürk (2000), Atatürk Anıtı, detay, Karabük 
Anıt, taş kaide üzerine hazır beton üçgen derzlerle yükselen taş kaplama üzerine bronz malzemeden yaptırılmıştır. Taş ve hazır betonun sağlamlığ 1 ile masif ağırlığ1 Cumhuriyet değerleri ve halkın gücünü simgelemektedir. Taşla kaplanmış beton kütle yukarıya doğru daralır şekilde yaptırılmıştır. Blok yüksekliği boyunca uzanan anıtta üstten aşağıya doğru akan bir anlatım yer alır. Bronz dökümü ile yapılan soyut betimlemeler aşağı doğru gittikçe belirginleşen portre figürlere dönüşür. Bronz malzeme Karabük kentinin ekonomik kaynağı olan demir-çelik sanayisini simgelemektedir. Farklı toplum kesimlerini kapsayan figürlerden üçü ise işçileri temsil etmektedir (Fotoğraf 23). Portrelerin en üstündeki yüz ifadeleri seçilebilen ilk üç figür işçi betimlemeleridir. Bu işçi portrelerinin altında sıralanan çeşitli figürler yer almaktadır. Böylece anıtta sosyal sınıflara ve meslek erbabına vurgu yapılırken en büyük temsil iş̧̧ilere yönelmiştir. Bu da anıtın bulunduğu kentin özelliğinden kaynaklanmıştır.

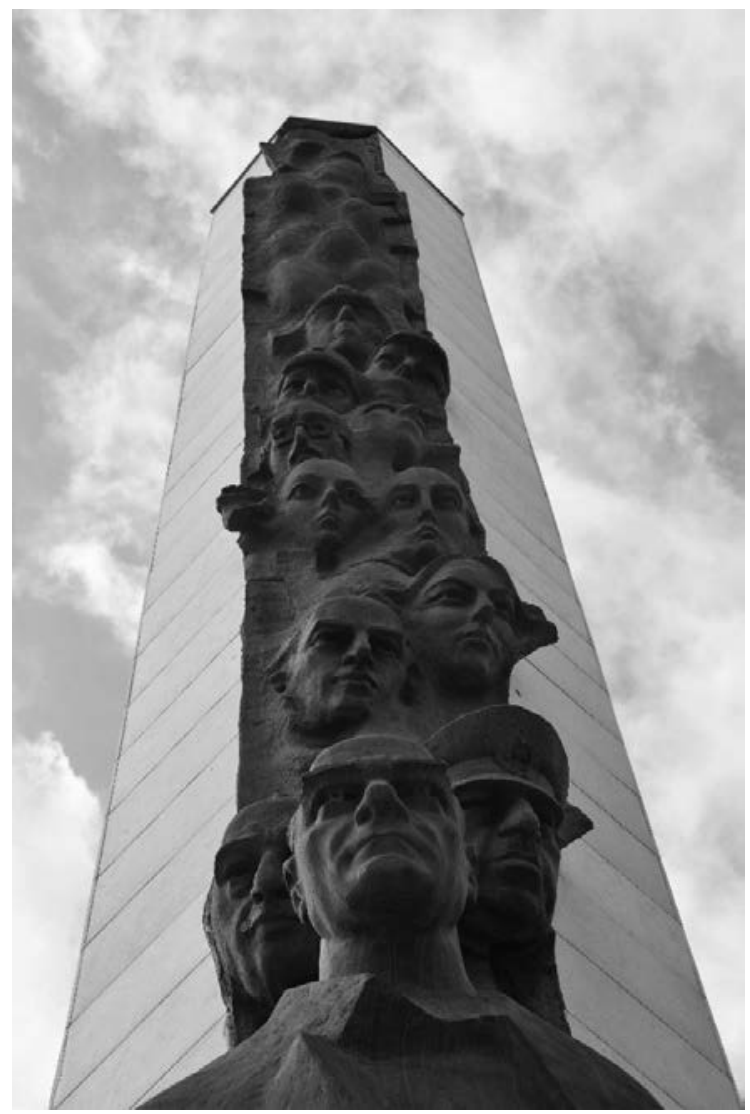

Fotoğraf 24. Ziyatin Nuriyev-Ümit Öztürk (2000), Atatürk Anıtı, detay Karabük 
Kent, işçi kentidir ve işçi vurgusu Atatürk portresiyle bütünlük kazanan modern Cumhuriyet'e de göndermede bulunmaktadır. İşçilerden aşağı doğru inildikçe Cumhuriyet'in diğer toplumsal kesimlerini temsil eden figürlerin devamında Mareşal Fevzi Çakmak ile İsmet İnönü gibi Kurtuluş Savaşı kahramanları betimlenmekte ve bütün bu figürler Mustafa Kemal Atatürk'ün gövdesinde vücut bulacak şekilde sonlanmaktadır (Fotoğraf 24). Atatürk Anıtı üniversitenin logosunu oluşturan fiskiyeli bir havuza doğru uzanır. Böylece Cumhuriyet'in değerleri, iş̧̧iler, geniş halk kesimleri ile ülkemizin geleceği olan üniversite gençliği ve akademi bütünleşir.

\section{Sonuç}

Ülkemizde Cumhuriyet'e ve kuruluş felsefesine atıfta bulunulan anıtlar hemen hemen tüm kentlerin meydanlarında görünür şekilde konumlandırılmıştır. Ülkemizin diğer kentlerinde olduğu gibi Zonguldak ve Karabük illerinde de Cumhuriyet ve kuruluş felsefesini temsil eden İnönü Heykeli ve Cumhuriyet Anıtları ile Zühtü Müritoğlu ve Ali Hadi Bara'nın (Üstünipek 2014: 273-284) yaptığı Atlı Atatürk Anıtı (Gezer 1994: 105-110) bu duruma örnektirler. Bunun yanı sıra kentlerin tarihi dokusu, yöresel özellikleri, yaşam kaynakları ve diğer önemli özellikleri de anttlarla temsil edilmiştir. Makaleye konu olan Zonguldak ve Karabük kentlerindeki işçi anıt heykelleri de bu duruma birer örnektir. Bu heykeller işçi kenti olan iki şehrin kamusal alanlarında konumlandırılarak vurgulanmıştır.

Zonguldak işçi anıt heykelleri Karabük kentine nazaran kamusal alanda daha fazla yer bulmuştur. Bunun nedeni kentin kuruluşundaki süreçte ortaya ç1kan gelişmelerdir. Zonguldak, Cumhuriyet kenti olarak başlangıçtan itibaren merkezi bir yerleşim yeri olmuştur. Karabük ise Zonguldak'ın gölgesinde uzun yıllar ilçe olarak kalmıştır. Zonguldak'ın büyük maden ocakları ile başlayan kentleşme serüveninin çağdaş yaşamı ve sanat etkinliklerini de beslediği görülmektedir. Zonguldak’ta çalı̧̧maya konu olan bu makalede doğrudan işçi temsilinin öne çıktığı beş anıt heykel yer alırken; Karabük'te biri doğrudan iş̧i temsilini, diğeri ise işçinin tamamlayıcı unsur olarak gösterildiği iki anıt yer almaktadır. Böylece her iki kent karşılaştırmalarında belirgin düzeyde bir çeşitlilik ortaya çıkar.

Anıt heykeller kentlerin merkezi noktasında yer alacak şekilde gerçekleştirilmiştir. Böylece kamusal alan kentin en önemli simgeleri ile tamamlanmıştır. Zonguldak ve Karabük kent dokularının zayıllı̆ı anıt heykellerin kamusal alandaki etkisini, herhangi bir Avrupa kent meydanındaki anıt heykelin ka- 
musal alana etkisiyle karşılaştırılamayacak düzeyde zayıflatır. Bu durum anıt heykellerin toplumsal karşılığını sorgulatır ancak, anıt heykeller kenti ve işçiyi temsil etmeyi de sürdürür (Fotoğraf 25, 26).

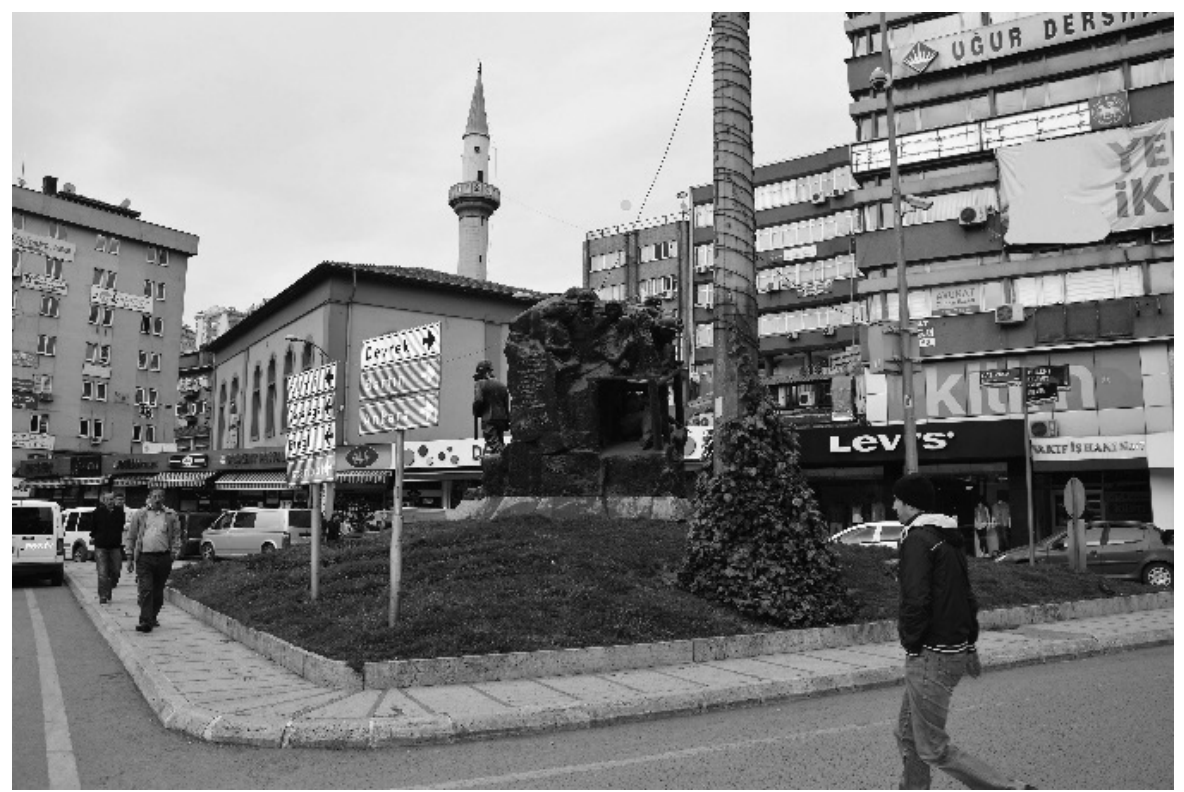

Fotoğraf 25. Zonguldak İşçi Anıtı

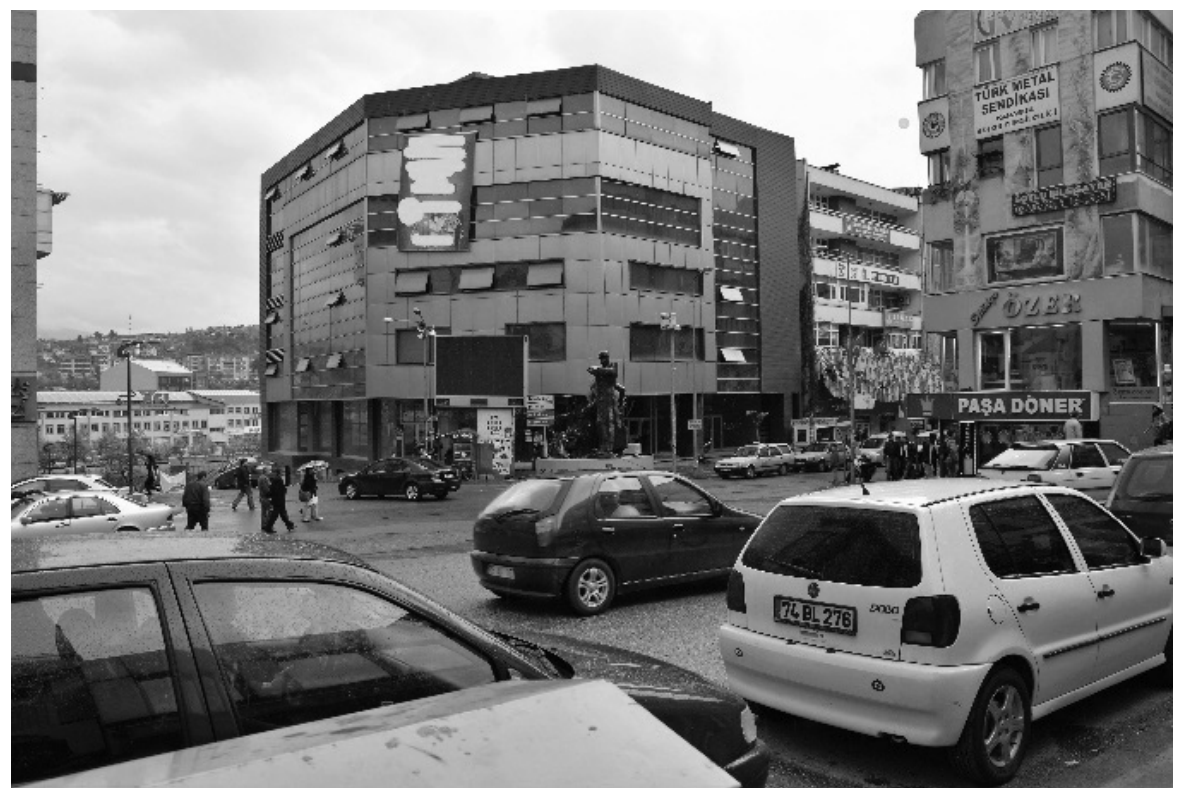

Fotoğraf 26. Karabük İşçi Anıt Heykeli 
Kamusal alanın güçlü olduğu yerlerde yapılacak anıtların yasal olarak ilgili kurumlardan izin alınarak yapılması ya da kurumların teklifi ile yapilıyor olması, belirlenen konunun gerçekleştirilmesinde görevli olan yetkililerin çoğunlukla sanat eğitimi almamış ya da sanat kavramına özsel yaklaşımdan uzak bir anlayışla hareket etmeleri neticesinde istenilen temsilin olabildiğince hızlı, bazen ucuz ve hatta belirledikleri sınırlar içerisinde kalma isteği sanatçıların özgünlükten uzaklaşmasına neden olabilmiştir. Bunun etkisiyle birçok sanatçı işini kaybetme vb. endişelerle düşüncede tam olarak bağımsız davranamamış, bu endişeler kimi zaman sanat kaygısının önüne geçmiştir.

Sanatçlların sanat kaygısı ile hareket etmesini engelleyen endişeler, gerçekleştirilen bazı anıt türündeki heykellerde görülmez. Bu örneklerde sanatçının duygu ve düşüncesinin anıtın bütününe güçlü bir şekilde yansıdığını görebiliriz. Haliyle koşullar ve koşulları etkileyen kişilerin çeşitli nedenlerle ortaya koydukları yaklaşımlar sanat yapıtının sürecini ve sanat kavramı içindeki yerini etkilemiştir.

Zonguldak İşçi Anıtı, Kozlu Madenci Heykeli, Karabük İşçi Anıtı ve işçinin tamamlayıcı olduğu Atatürk Anıtı adlı yapıtlarda sanatçıların sanat anlayışlarını anıtlara diğer anıtlara nazaran daha fazla yansitabildikleri görülmektedir. Zonguldak ve Karabük'teki anıt heykeller ortak özellikler göstermekle beraber farkl11klara da sahiptirler. Bu farklilıklar konu ve üslup bakımından çeşitlilik göstermektedir.

Heykeltıraş Tankut Öktem İşçi Anıtı'nda işçiyi, heykeltıraş Aslan Başpınar Uzun Mehmet Anıtı'nda Uzun Mehmet'i belgesel niteliğinde anlatımcı bir dilde anıta taşımışlardır. İşçi Anıtında mekân olarak maden ocağı içerisinde figüratif heykel anıtı yazı ile desteklenmiştir. Uzun Mehmet Anıtında ise rölyefler anıttaki anlatımcı üslubu destekler. İşçi anıtında sanatçının anlatımcı dili klasik heykel özelliklerindeki Cumhuriyet'in çağdaş normlarını ve yaşantısını aktarmayı işçi ile bütünleştirmek istemesinden kaynaklanır. Uzun Mehmet heykeli ve anıtın kaidesindeki rölyeflerde yöresel kıyafetler içerisindeki Uzun Mehmet ve annesi ile maden ocağ1 ve işçiler realist anlayışta betimlenmiştir.

İşçi temsiline sahip anıt heykellerde konular figürlü kompozisyonlara sahiptir. Figür, Zonguldak Havzası Maden Şehitleri Anıtı dışındaki işçi anıtlarının tamamında görülmektedir. Bu figürler işçi kimliklerini vurgulayan, öne çıkaran iş̧̧i kıyafetleriyle birlikte betimlenmiştir. İşçiyi temsil eden figürler genellikle çalıştıkları yerde ya da çalışırken betimlenmiştir.

Anıtlar sadece figüratif bir anlatımla ortaya çıkmazlar. Yazılar da betimlemelerin birer parçasıdırlar. Antik Roma zafer taklarında üç boyutlu figürler, 
rölyefler ve yazılar birlikte bir kompozisyon oluşturmuştur. Bu manada anıtlara yazının dahil edilmesi zamanla daha sık görülür. Örneğin; günümüzde İstanbul Sultan Ahmet Meydanı'nda yer alan Yılanlı (Burmalı) Sütun'da Yunan şehirlerinin Perslere karşı birleşmesi anısına 33 Yunanlı Şehir Devleti adlarının anıt üzerinde yazılı olması dikkat çekicidir. Bu düzeyde her bir isim bütünün birer parçasını oluşturur. Böylece kendi kimlikleri üst bir kimlikte hayat bulur. Maden Şehitleri Anıtı'nda da benzer bir durum söz konusudur. Maden kazasında ölen madencilerin her birinin ismi anıtta ayrı ayrı yer alırken, aynı pano üzerinde isimlerin yan yana ve üst üste betimlenmesi bir üst kimliğe işaret eder. Bu kimlik 'madenci'dir (bkz. Fotoğraf 8, 9 ) (Oral, 2017).

Bir diğer yazının kullanıldığı anıt Zonguldak İşçi Anıtı'dır. Bu anıtta Mustafa Kemal Atatürk'ün özlü sözü cumhuriyet değerlerini işçi ile buluşturarak anıtı ve kenti bütünler. Atatürk Anıtı'nda taş kaplama duvarın bir yüzünde kitabe yer alır. Diğer anıtlarda heykeltıraşların adlarının yazılı olduğu imzalar dışında yazıya yer verilmemiştir.

Polyester, çelik, taş, bronz, pirinç, cam elyaf, çakma andezit, hazır beton, mermer mozaik vb. malzemelerin kullanıldığ anıtlarda maden ve sanayi kentlerini domine eden işçiler genellikle figürlü kompozisyonlar içerisinde temsil edilmişlerdir.

İşçi temsiliyetinin vurgulandığı anıtlardaki klasik heykel anlayışı, çoğu zaman sembolik nitelikte realist bir anlatım ve idealize edilmiş klasik bir yaklaşımla verilmiştir. Anıt heykellerde gerçekçilik idealize edilen formlara hapsolmuştur. Sanatçılar anıta konu olan iş̧̧i ve buna bağlı yaşam koşullarını betimlerken kimi zaman duygusal yaklaşımlarını da öne çıkarmışlardır. İdealizm içinde iş̧̧i ve emek yüceltilmiş, bu yüceltmeler çoğu zaman realist çizgilerle ifade edilmiştir. Zonguldak İşçi Anıtı, Ereğli Uzun Mehmet Anıtı, Kozlu Madenci Heykeli klasik heykel sanatı anlayışında, Zonguldak Madenci Anıtı postmodern yaklaşımla, Karabük İşçi Heykeli post-empresyonist etkide Kübist tavrı ve modern çizgileriyle diğer anıtlardan ayrışır. Karabük Atatürk Anıtı ise, ülkemizin kuruluş felsefesini temsil eden figürler ile anıtın yapıldığg kente has işçi temsilini, halkla beraber vurgulayarak oluşturulan kompozisyon, bir meydan düzenlemesi içinde anlatımcı üslupta postmodern soyut anlatımcıl1$\breve{g} 1$ ve realist çizgileri klasik anlayışla buluşturur. 


\section{Kaynaklar}

Ahıska, Meltem (2011). "Hatırlayan Ucubeler: Tophane'deki İşçi Anıtının Hikâyesinin İzini Sürmek” Red Thread 3, s. 1-21.

Aydın, Uzun Derya (2016). Türk Heykel Sanatı ve İlk Heykeltıraşlar, Ankara: Gece Kitaplığı.

Avşaroğlu, Nadir (2008). "Marshall Planı, Amerikan Dış Kredileri ve Türkiye Madencilik Sektörüne Etkileri”,

Berk, Nurullah; Gezer Hüseyin (1973). 50 Yılın Türk Resim ve Heykeli, İstanbul: Türkiye İş Bankası Kültür Yayınları.

Bulat, Mustafa; Bulat, Serap; Yağmur, Önder ve Aydın, Barı̧̧ (2014). "Modern Türk Heykel Sanatı'nın Doğuşu”, Akademik Sosyal Araştırmalar Dergisi 2/2, s. 363-374.

Cezar, Mustafa (1995). Sanatta Bati'ya Açılış ve Osman Hamdi, İstanbul: Erol Kerim Aksoy Kültür, Eğitim, Spor ve Sağlık Vakfı Yayınları.

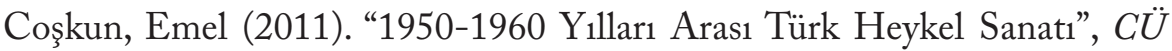
Sosyal Bilimler Dergisi 35/2.

Erten, Oğuz (2012). Türk Plastik Sanatlarında İlkler, İstanbul: Artam Antik A.Ş. Kültür Yayınları.

Genç, Hamdi (2010). "Cumhuriyet'in İlk Yillarında Zonguldak'ta Nüfus, Ticaret ve Sanayi (1920-1932)”, ZKÜ Sosyal Bilimler Dergisi 6/12.

Gezer, Hüseyin (1994). Cumburiyet Dönemi Türk Heykeli, Ankara: Türkiye İş Bankası Kültür Yayınları.

Giray, Kıymet (1997). Müstakil Ressamlar ve Heykeltıraşlar Birliği, İstanbul: Akbank Yayını.

Günsel, Renda (2002). “Osmanlılar'da Heykel”, Sanat Dünyamız Dergisi 82, s. $139-144$.

Kanberoğlu, Atıcı Nesrin (2012). "Osmanlıdan Cumhuriyete Heykel Sanatının Yolculuğu”, History Studies Internatıonal Journal of History, 4/4, s. 171-189.

Kedik, Sibel Ayşe (2011). 'Kamusal Alan, Kent ve Heykel İlişkisi' Anadolu Üniversitesi Sosyal Bilimler Dergisi 11/1, s. 229-240.

Kuban, Doğan (1973). “Anıt Kavramı Üzerine Düşünceler”, Mimarlık Dergisi 7, s.7-9. 
Sabahat, Sezer Nihat (2017) “Türkiye'de anıt Heykelin Temsil ve Kimlik Sorunu" İdil Dergisi 6/31, s. 953-966.

Oral, Bülent (2017). "Bir Anıtın Enstalasyona Dönüşümü: Zonguldak Havzası Maden Şehitleri Anıtı” Hacettepe Üniversitesi Türkiyat Araştırmaları Dergisi (HÜTAD 27).

Osma, Kıvanç. (2003). Cumburiyet Dönemi Anıt Heykelleri (1923-1946). Ankara: Atatürk Araştırma Merkezi.

Özsezgin, Kaya (2006). "Zühtü Müridoğlu, Resim, Heykel: Bütün Bir Yaşam”, Sergi, 24 Şubat-14 Nisan 2006, İstanbul: Yapı Kredi Kazım Taşkent Sanat Galerisi.

Sözen Metin- Tanyeli Uğur (1994). Sanat Kavram ve Terimleri Sözlüğ̈̈, İstanbul: Remzi Kitabevi Yayınları,

Tansuğ, Sezer (2003). Çă̆daş Türk Sanatı, İstanbul: Remzi Kitabevi.

Tekiner, Aylin (2010). Atatürk Heykelleri, İstanbul: Kült, Estetik, Siyaset İletişim Yayınları.

Üstünipek, Mehmet (2014). Ali Hadi Bara “Ali Hadi Bara’nın Anıt Heykel Alanındaki Öncü Kimliği ve Uygulamaları”, Semra Germaner Armağanı, İstanbul: MSGSÜ Yayınları.

Yasa, Yaman Zeynep (2011). 'Siyasi/Estetik Gösterge' Olarak Kamusal Alanda Anit ve Heykel, METUJFA 28/1, s. 177-190.

Yılmaz, Nahide Ayşe (2006). "Ali Hadi Bara ve Atölyesi: Türk Heykelinde Yeni Oluşumlar”, yayımlanmamış yüksek lisans tezi, Ankara: Hacettepe Üniversitesi.

Yüksel, Mustafa (2012). “1980’lerden sonra Türk Heykel Sanatının Diğer Sanat Hareketlerindeki Yeri”, Ç.Ü. Sosyal Bilimler Enstitüsü Dergisi 21/2, s. 91-102. 


\section{ABSTRACT \\ Representation of Worker on The Monument Sculptures in Zon- guldak and Karabük Cities}

Sculpt is defined as transforming the artist's materials into three dimensional expressions that have certain weight and scope. If the sculpt is dedicated to a certain case or to a person/people who involved in that case, it is called as monument sculpture. Some of these monuments can manage to remain in accordance with the society's level of culture/art or sometimes, they vanish due to various reasons. Altough these structures have strong meanings in their representation of things, one of the important reasons of their disappearence is because the society could not understand their meanings thus, these meanings got weaker through time and they diminished. Throughout history civilizations have built monument sculptures for purpose. Turkish sculpture has also seen sculptures in the form of monuments in accordance with the spirit of the time. These include monument sculptors on the Ataturk and Independence War, sculptures of personalities as Architect Sinan and Nasrettin Hoca. West Black Sea Region cities Zonguldak and Karabük are the cities occured after industrial revolution. Zonguldak is known as coal miner's city whilst Karabük is known as industrial worker's. In this article, the worker's monument, miner's monument, mine martyr's monument, Uzun Mehmet monument, Kozlu miner monument are analized along with the worker monument sculpture and Atatürk monument in Karabük. By doing so, it is aimed to understand and study representations of workers who are the core factors of these cities' population and growth and their reaction on art, artist, ruling class and their relations between society. These evaluations are studied with artistic style and comments. The ruling artistic understanding of these worker represented monuments is classicism. The classical understanding has ideological approaches in realistic expressions. Also, it is possible to see examples of cubic and intengible expressions in monuments in late impressionist effect.

Keywords: Monument Sculpture, Worker, Miner, Zonguldak, Karabuk, Modernism, Classicism. 